\title{
Iconic Flora of Heritage Significance in India
}

\author{
H Y Mohan Ram*
}

(Received 08 February 2016 ; revised 16 May 2016)

\begin{abstract}
Indian subcontinent is rich in flora for its variable geo-climatic conditions. It is not easy to select some plant species as iconic. However, a short list of plants has been prepared which Indians have valued for their well-being, culture and esteem.

The banyan (Ficus benghalensis) is the National Tree of India and tops the list. Beginning as an individual sapling, it can produce an enormous forest with pillar-like prop roots. The Bodhi tree or peepul (Ficus religiosa) occurs in India and some neighbouring countries and is venerated by the Hindus, Buddhists and Jains. Gautama Buddha attained enlightenment under the peepal tree at Bodh Gaya in Bihar. Emperor Ashoka's daughter Sanghamitra, a Buddhist nun, took a branch of this famous tree and planted it in Anuradhapura in Sri Lanka in 288 BC. People worship it as ‘Jaya Sri Maha Bodhi’.

Neem (Azhadirachta indica) a most useful tree, has leaves with bitter taste. Probably a native of Burma it is cultivated abundantly in India. Neem is a source of azhadirachtin, an anti-feedant botanical pesticide, chew sticks for brushing teeth, a non-edible oil, firewood and fodder. Sheesham (Dalbergia sissoo) is the source of an exquisite wood, used for carving, and supports artisans. Nepalese use it for decorative windows with frames. Tamarind (Tamarindus indica) is a tree indigenous to tropical Africa and must have come to India a long time ago. The pulpy fruits are rich in vitamin $C$ and other useful nutrients used in various culinary preparations. The tamarind wood charcoal has a high thermal heat, popular among traditional Indian jewelers.
\end{abstract}

Sandalwood (Santalum album) is a small tree and its heartwood yielding 'candana' (candan) is nurtured for its sacred aroma. Artistic idols of gods and saints are carved out of it. It is also used in perfumery as a fixer and in the manufacture of soaps, cosmetics and aromatherapy.

$\bar{A} m l \bar{a}$ (Emblica officinalis), a fleshy edible fruit rich in antioxidants is used in Ayurvedic medicines and hair dyes. The endocarp having typical markings on its surface is a motif in Hindu temple architecture.

Haldi or turmeric (Curcuma longa) is a rhizome which is boiled, polished and sold in solid or powdered form. India is the largest producer of turmeric in the world. It is used as a dye and in curry powder and has wound healing, anti-inflammatory, anti-fungal, antioxidant, and anti-cancer properties. It plays an important role in pre-wedding rituals of the brides among both Hindus and Muslims.

Pārijāta or Śefalikā (Nyctanthes arbor-tristis) is a shrub blooming at night with a delicate smell that occurs all over India and neighbouring countries. Its corolla is also used for dying robes for Buddhists.

Coconut palm (Cocos nucifera), also known as 'kalpavrksa' has hundreds of uses. It occurs along all coastal regions of tropical seas and in interior regions. The fleshy endosperm is a food item consumed in several ways. Oil extracted from copra is used for cooking, and in hair and skin care products. The coconut fibre (coir) has myriad applications.

A few other iconic plants such as banana, palmyra palm, bamboo, black pepper and cardamom have also been discussed.

Key words: Āmla, Anuradhapura, Arthaśāstra, Bamboos, Black pepper, Bodhi tree, Cardamom, Coir, Jack, Musical instruments, Nabakalebara, National Tree, Neem, Palm leaf manuscripts, Sandalwood, Sheesham, Tamarind, Turmeric, Wood, Woodcarving

\footnotetext{
* INSA-Srinivasa Ramanujan Research Professor, Shriram Institute for Industrial Research, 19, University Road, Delhi-110 007; E-mail: hymohanram@gmail.com
} 


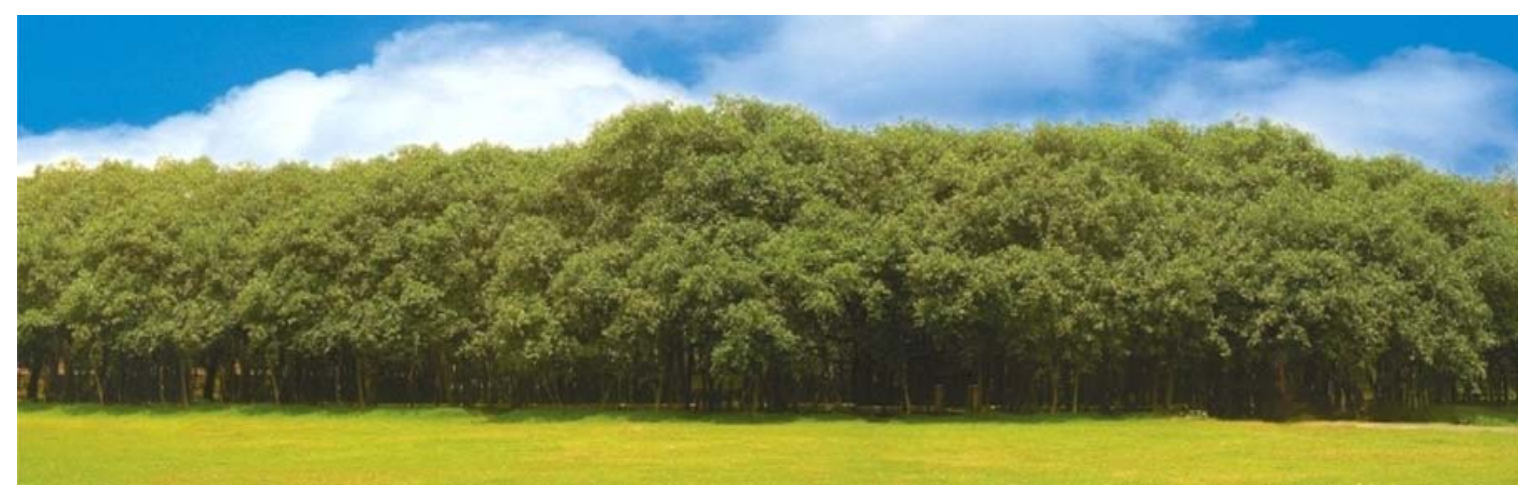

Fig. 1. The legendary banyan in the Acharya Jagadish Chandra Bose Indian Botanic Garden, West Bengal

The term flora refers to plant life occurring in a particular region, habitat or geographical period. In a country of the size of India with such varied geo-climatic conditions, antiquity, high population growth and enormous variability of cultural practices, it is truly a daunting task to attempt to select some elements of Indian Flora as iconic. Nevertheless, a short list has been prepared including those valued or even venerated by the people of India in their daily life, cuisine, customs, culture and well-being.

\section{The Banyan Tree}

The Banyan Tree (Ficus benghalensis L. of the family Moraceae) is an enormous tree and represents eternal life. It has branches that not only form a massive canopy but also grow downward, penetrate the earth and produce pillar-like structures and develop into what appears like a forest. The tree lives for hundreds of years. Besides yielding traditional remedies, the banyan is a keystone species that provides shelter, food, feed and fodder to a large variety of animals-insects, snakes, birds, bats, squirrels and monkeys. This tree represents India and its people from different races, religions and communities. The tree is worshiped by the Hindu women for a long and happy married life. No wonder this magnificent tree is aptly declared the National Tree of India.

The legendary banyan in the Acharya Jagadish Chandra Bose Indian Botanic Garden
(AJCBIBG), Howrah, in West Bengal occupies an area of 1.84 hectares and bears 3772 prop roots (as of June 2015) is about 250 years old. The Garden with the Great Banyan Tree is shortlisted as one of the seven wonders of West Bengal (Fig $1)$.

Thimmamma Marrimanu, another individual banyan tree listed in the Guinness World Records (1989) is located in Gootibayalu near Anantapur in Andhra Pradesh. It occupies an area of 2.02 hectares with a canopy of 1.9 hectares (Fig 2). In the present author's considered judgement very soon the tree in West Bengal is likely to out grow the Gootibayalu tree on account of higher rainfall and high humidity. The tree in Gootibayalu is surviving under severe moisture stress conditions.

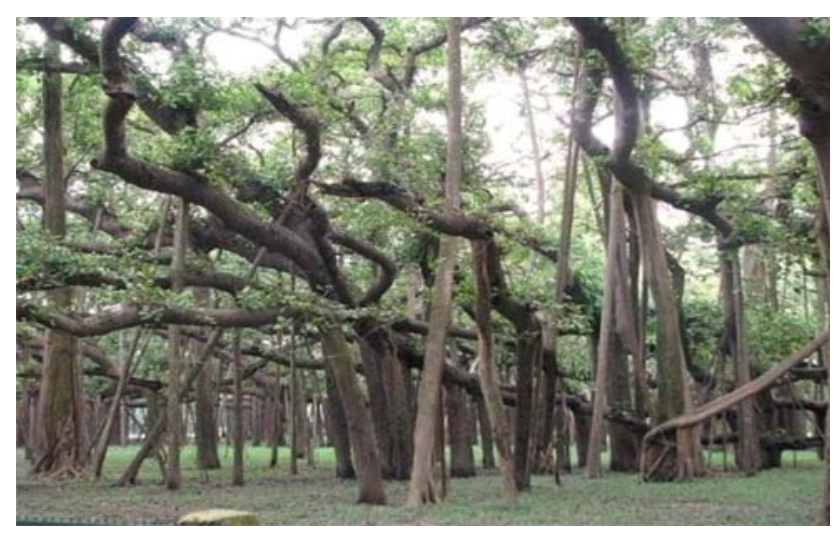

Fig. 2. Thimmamma Marrimanu, an individual banyan tree listed in the Guinness World Records (1989), Andhra Pradesh 
There are a few more massive banyan trees, for example in Kettohalli (locally named Dodda alada mara in Kannada) about $28 \mathrm{~km}$ from Bengaluru (close to the Bengaluru-Mysuru Road) (Fig. 5) and another in the campus of the Theosophical Society, Adyar, Chennai. A sapling of this tree was planted in the Kalakshetra campus by Rukmini Devi Arundale in 1951. It has now grown into a magnificent tree (Fig. 3) bearing red to reddish orange figs (Fig. 4). The name Vadodara (Baroda) is derived from the Sanskrit word Vatodara meaning in the heart of banyan tree. The early travellers observed that the shade of the tree was frequented by the baniyās or the Indian traders. In the Guajarati language 'baniya' refers to a grocer/ merchant. The Portuguese picked up the word to refer specifically to Hindu merchants and passed it along to the English as early as 1599 with the same meaning. By 1634, English writers began to tell of the banyan tree -a tree under which Hindu merchants would conduct their business. The tree provides a shaded place for village
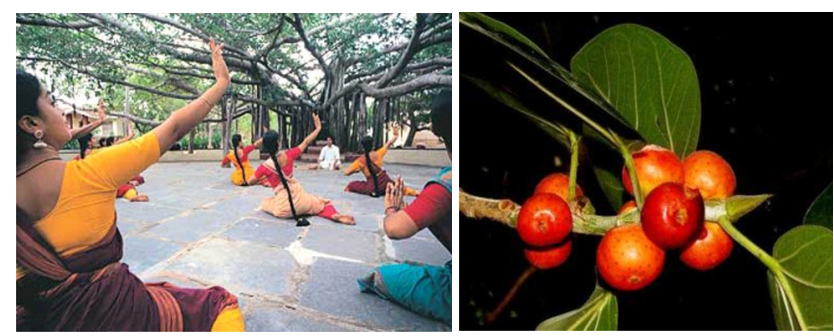

Fig. 3 \& 4. Banayan Tree with its red to reddish orange figs, planted in Kalakshetra campus by Rukmini Devi Arundale in 1951

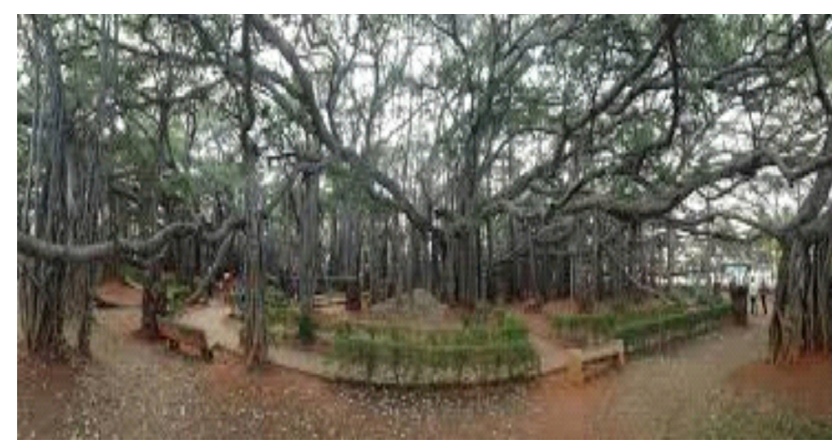

Fig. 5. Banayan Tree in Kettohalli (locally named Dodda alada mara in Kannada) about $28 \mathrm{~km}$ from Bengaluru meetings or for merchants to sell their goods. Eventually 'banyan' became the name of the tree itself.

\section{Peepal}

Ficus religiosa L. commonly known as pipal tree, bodhi-tree, Bo tree, pippala, or aśvattha, is a large evergreen tree found throughout India (Fig.6). It is native to Nepal, India, Bangladesh, Myanmar, Pakistan, Sri Lanka, Southwest China and Indo-China. Mature leaves have a heartshaped base attached to a long slender petiole with an elongated drip-tips (Fig. 7), which make them tremulous.

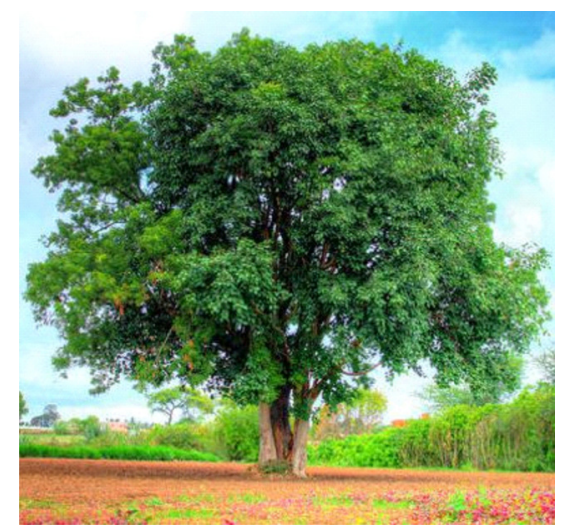

Fig. 6. A pippala tree (Ficus religiosa)

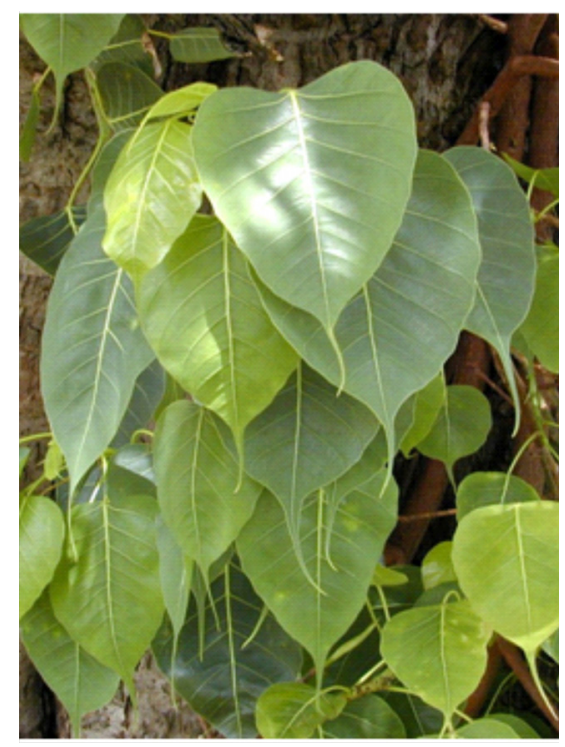

Fig. 7. Young leaves with heart-shaped base attached to a long slender petiole with an elongated drip-tip 
It is mentioned in the Bhāgavad Gìtā that Gods reside on the leaves and make them move continuously. Hindus, Buddhists and Jains consider peepal a sacred tree. Siddhartha Gautama attained enlightenment (bodhi) while meditating under a pippala tree and came to be known as Buddha later. The site is in the present day Bodh Gaya in Bihar, India (Figs. 8, 9).

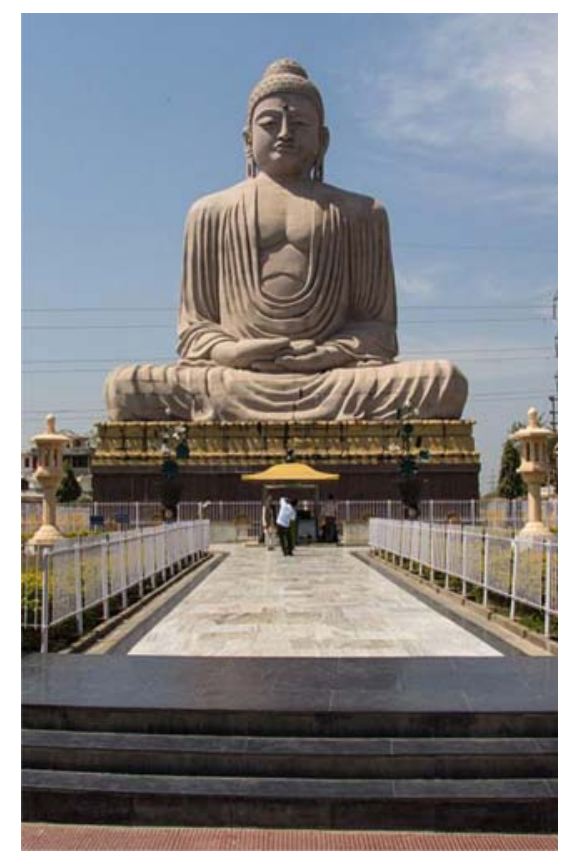

Fig. 8. Buddha's statue at Bodh Gaya in Bihar

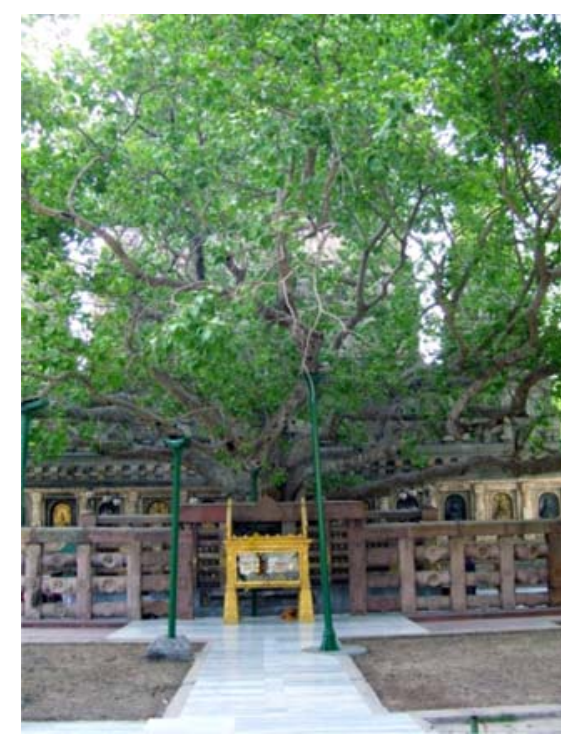

Fig. 9. The lower part of Bodhi Tree in Bodh Gaya, Bihar
A sapling of the Bodhi tree was carried by Ashoka's daughter Sanghamitra to Anuradhapura in Sri Lanka in 288 BC (Fig.10) and planted there (Pande \& Pande, 2015). It has now grown into a magnificent tree and is presently known as Jaya Sri Maha Bodhi (Fig. 11). This tree is synonymous with the living Buddha. It is the oldest tree in the world with a record of written history. The ages of other old trees round the world are only estimations. It is a common practice among Hindus and Buddhists to do seven pradakșinās (circambulations) of this sacred tree. A seal discovered in Mohenjodaro, of the Indus Valley Civilization depicts the pippala tree defended by a mythical guardian spirit from evil forces.

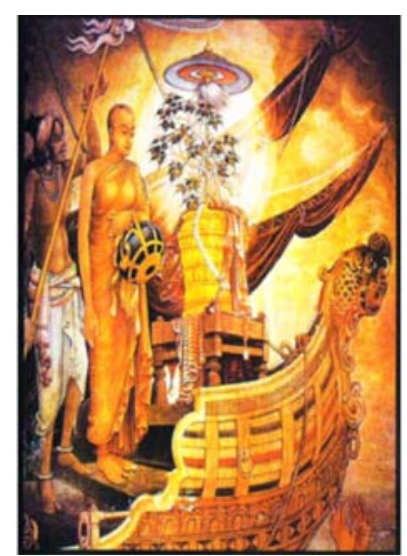

Fig. 10. A wall painting at Kelaniya temple, Colombo showing Sanghamitra carrying a sapling of the Bodhi tree to Sri Lanka

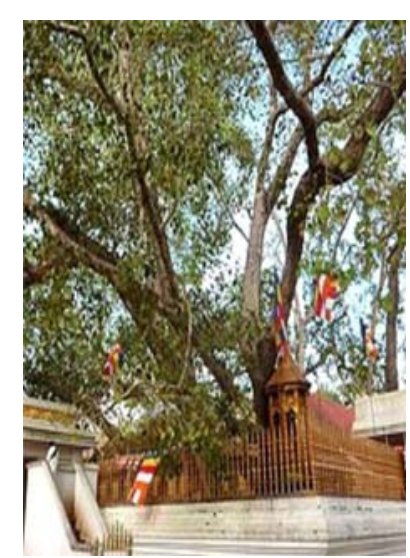

Fig. 11. Jaya Sri Mahā Bodhi tree in Anuradhapura, Sri Lanka

\section{SANDALWOOD}

Santalum album L. is a valuable tree of medium height, sacred and closely associated with Indian culture. The tree if well protected and tended could become a large tree (Fig. 12 a), bearing branches with axillary and terminal flowers. The fruits are green and later turn to red and purple at maturity (Fig. 12b).

Semiparasitic by nature, it produces one of the most expensive woods in the world. Sandalwood oil is extracted from the heartwood, (Fig. 13) which is highly fragrant. 


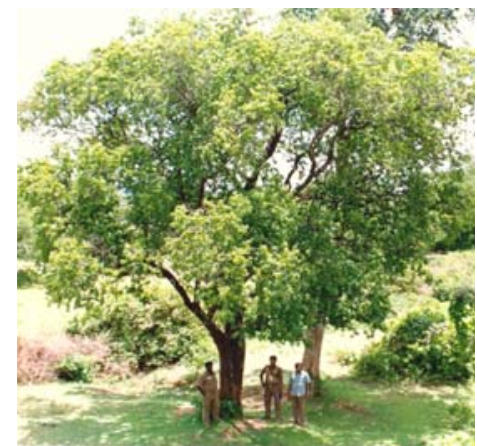

Fig. 12 a. An unusually large sandalwood tree showing optimum growth it can attain

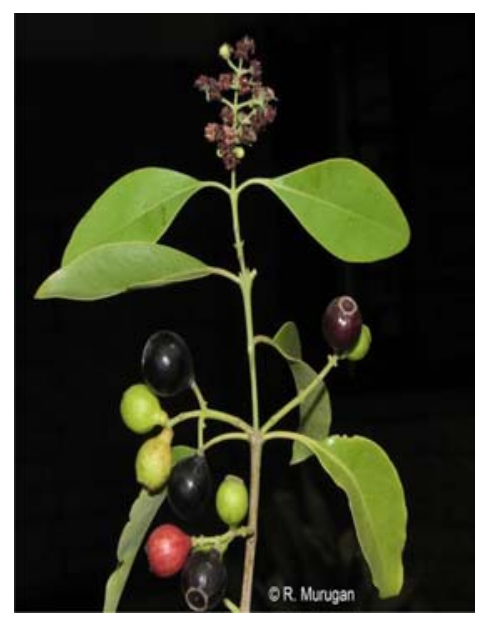

Fig. 12 b. A portion of flowering shoot displaying young and mature fruits

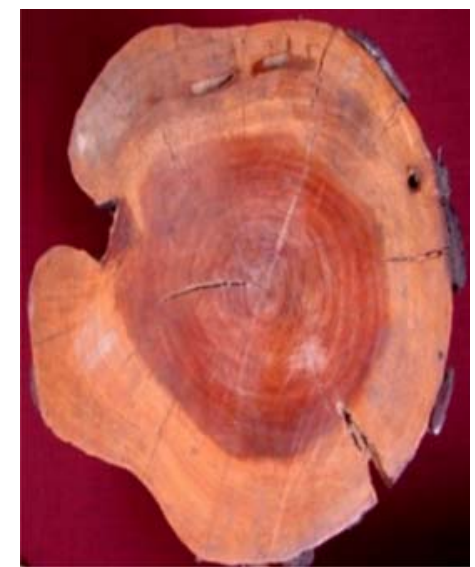

Fig. 13. Sandalwood disc showing darker heartwood and paler sapwood in the periphery.

Sandalwood oil is a pale-yellow to yellow, viscous liquid with a rich persistent aroma. It is expensive (Rs 300,000/- kg) and highly sought after in perfumery, cosmetics, aromatherapy and pharmaceuticals. The main property of the oil is attributed to its being a good fixer to bring together and hold most of the ethereal notes of other perfumes. Although the two main ingredients of sandalwood $-\alpha$ and $\beta$ santalols have been synthesized, these lack the quality of the whole oil and the pharmaceutical industrial needs are not being met. Hence, there is a perpetually high demand for the whole genuine natural oil from India. Sandalwood oil is also used as a flavouring agent in food products, desserts, non-alcoholic beverages and is an approved item by the U.S. Food and Drug Administration. A large number of medicinal uses of sandalwood have been mentioned in Āyurveda.

The tree is native to Indian sub-continent, especially in the regions where Tamil Nadu, Kerala and Karnataka meet. The heartwood of the tree is one of the finest natural materials for carving (Figs. $14,16)$. The carved images of gods and mythological figures have a high demand in the world market. Sandalwood is a traditional item in religious ceremonies and is offered in consecrated fire and in the Hindu cremation pyres. The sapwood is not scented and is coloured white or pale yellow, used in preparing turnery items and in the manufacture of agarbattis (incense sticks) (Fig. 15).

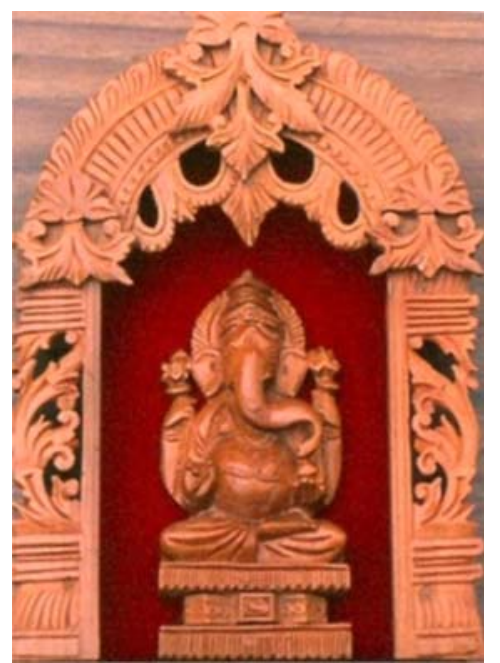

Fig. 14. Idol of Ganeśa made of heartwood 


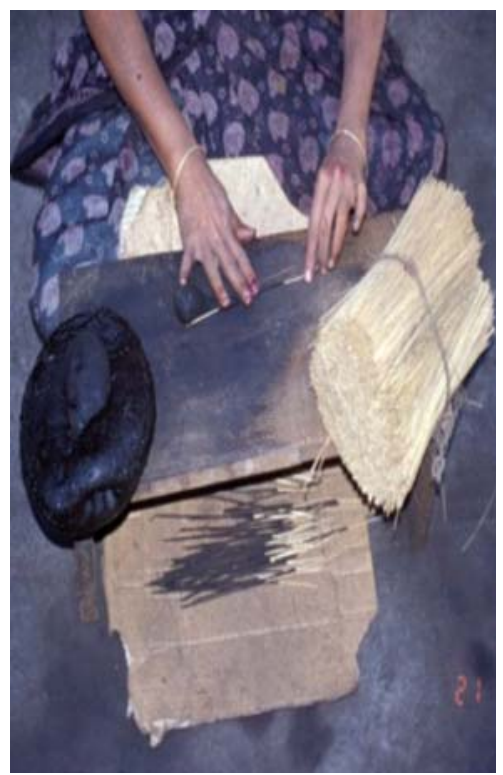

Fig.15. Rolling of agarbattis (incense sticks) in a factory in Mysuru

During the past 100 years, the availability of sandalwood has dwindled enormously owing to excessive harvesting without sufficient replenishment. Santalum album has been declared a vulnerable species by the International Union for Conservation of Nature (IUCN). A serious setback for sandalwood is the spike disease caused by phytoplasma. It destroyed a large number of mature trees in the former state of Mysore (now
Karnataka). There is no other plant subjected to such large-scale smuggling. The sandalwood tree has always been considered a Royal tree, even from the time of Tipu Sultan (1750-1799 AD), followed later by the rulers of the former Mysore State. The Karnataka Government used to own every tree. It is only recently that the ban has been lifted to encourage people to grow and take care of their own trees. Unfortunately, this move has backfired. Many large trees have been cut down even from well-guarded institutions such as the Indian Institute of Science and the Institute of Wood Science and Technology, Bengaluru.

A notorious brigand Veerappan who took to extensive smuggling of sandalwood with his gang was involved in killing over 184 forest guards including senior police and forest officials and even a Minister of the Karnataka State Government. The gang had abducted the famous film star Raj Kumar for a high ransom. Veerappan evaded arrest for 20 years until the Tamil Nadu and Karnataka joint police action shot him dead in 2004.

It is suggested that corporate bodies should step in to cultivate sandalwood under expert guidance and vigilance, extract the wood at the most useful time, and harvest it to maximize the

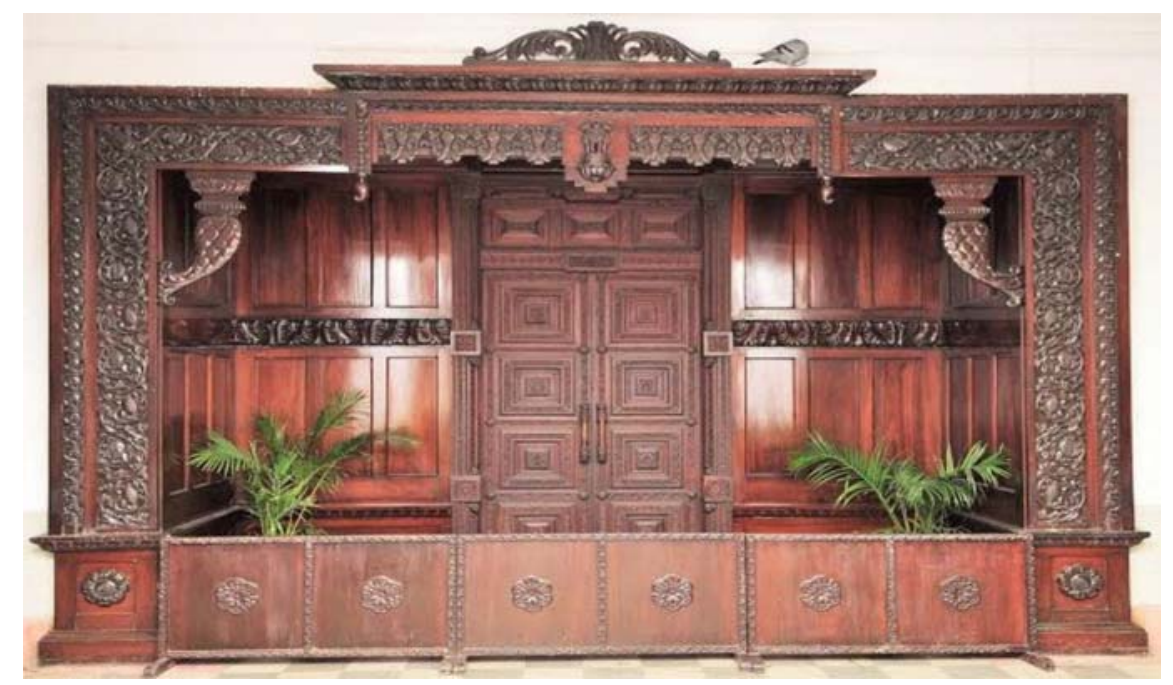

Fig. 16. The exquisitely carved sandalwood door leading to the cabinet room is a spectacular feature of the imposing building at Vidhana Soudha in Bengaluru 
benefits occurring from exports, and supply it to the sandal wood carvers (Gudigars) who have been deprived to practice their traditional art of carving.

\section{Bamboos}

Male bamboo [Dendrocalamus strictus (Roxb.) Nees] has been identified as an iconic plant (Fig. 18). However, it represents all bamboos (Fig. 17) - the woody grasses (Family Gramineae or Poaceae) of India. Bamboos provide food, housing and building materials and an endless number of valuable goods and services to humans and as feed to wild herbivores. Distributed throughout the tropical and subtropical parts of the world, bamboos constitute an important group of non-timber forest products of India. The qualities unmatched by any other plant group are their abundance (in the past), strength, low weight, durability, lustrous finish and beauty.
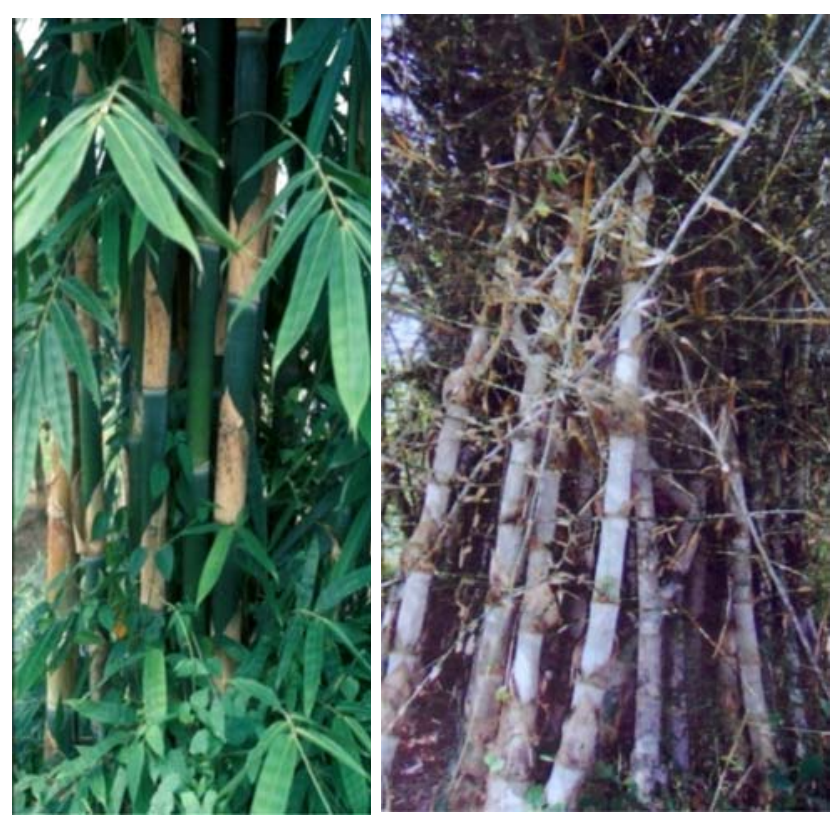

Fig. 17. A typical bamboo clump showing culm shoots, leaves and sheaths (left)

Fig. 18. A clump of Dendrocalamus strictus. Note the surface of stems covered with epicuticular wax (right)

Every bamboo has an infinite number of local uses. Bamboos grow naturally as understorey in many types of forests, especially in the northeastern states of India. Their distribution is largely governed by rainfall (minimum of $100 \mathrm{~cm}$ ) and temperature from 8-36 degree C. In India, bamboos occupy $12.8 \%$ of the total forest area (including the plantations). Northeastern India accounts for 58 species belonging to 16 genera.

Dendrocalamus strictus is the most widely distributed species and predominantly found in the dry deciduous forests of India notably in Madhya Pradesh, Uttar Pradesh, Maharashtra, Karnataka, Gujarat and Rajasthan.

Bamboos are everything to some people and some things to every person (MacClure 1966). It is very easy to handle the bamboos. A thick cast iron knife is all that is needed to cut the harvested bamboos, which are generally covered with epicuticular wax. Splits or strips of any width or thickness serve to prepare mats or baskets of various sizes (Figs. 19, 20, 21). The culm shoots

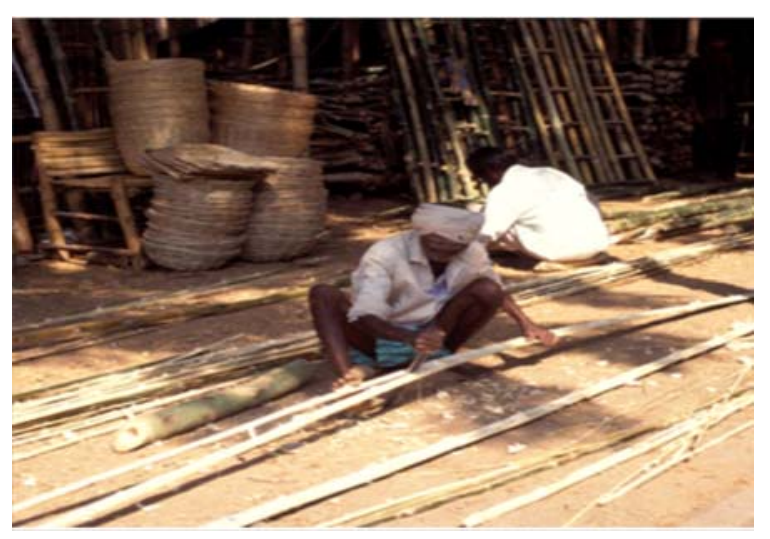

Fig. 19. Splitting of culm (shoot) of bamboo using a thick knife

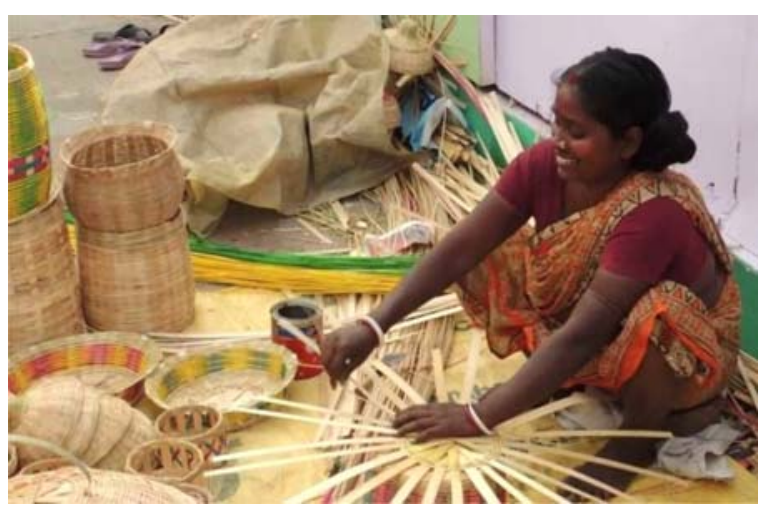

Fig. 20. A woman weaving a basket 


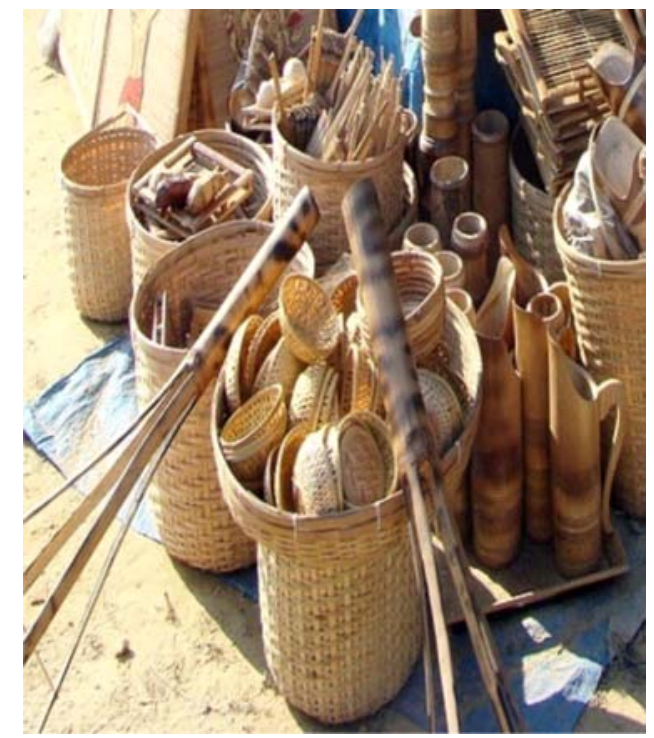

Fig 21. A variety of bamboo products

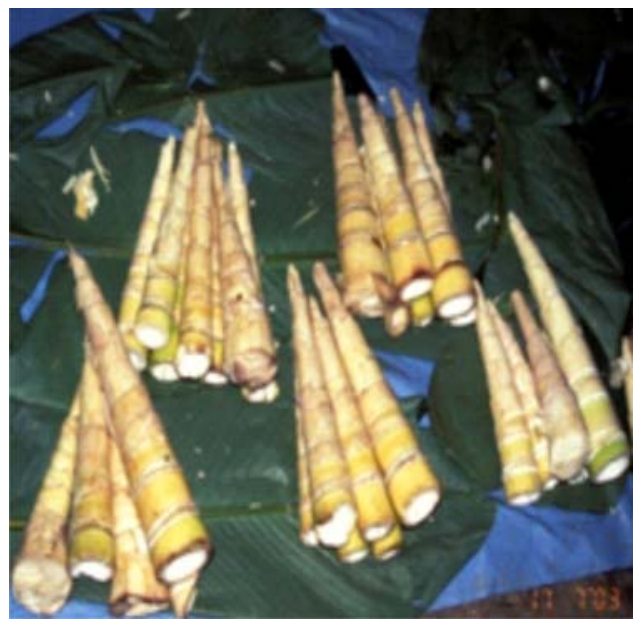

Fig 22. Fresh culm shoots of edible bamboo from a market on way to Shillong

of several bamboos are a common item of food (cooked, pickled or fermented) (Fig. 22).

Large whole bamboos are used for poles in construction work. Nearly all the oars of boats used in Southern and Eastern India are made of Bamboo. Circular bamboo trays have been used to rear mulberry silk worms (Figs. 23a, 23b, 24a, 24b). Rafts, fish traps, hand fans and even solid latthis (used by the police) are some of the most common items made from Dendrocalamus strictus. Bamboo wickerwork is a traditional craft

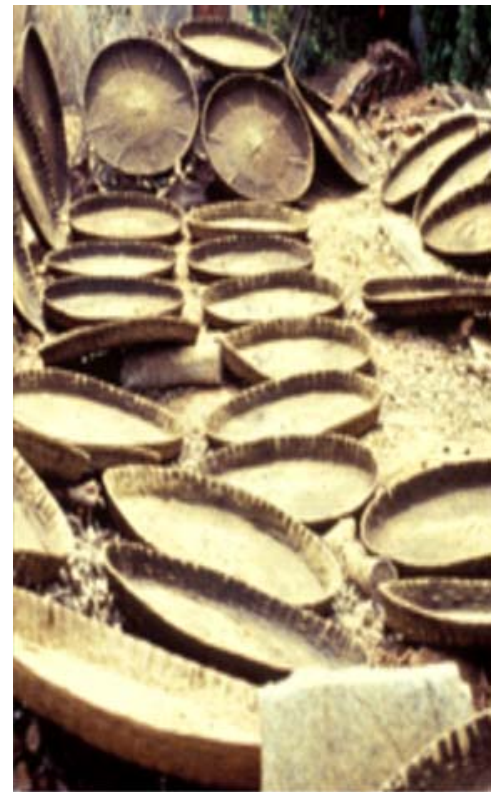

Fig 23a. Typical round bamboo trays used for rearing silk worms

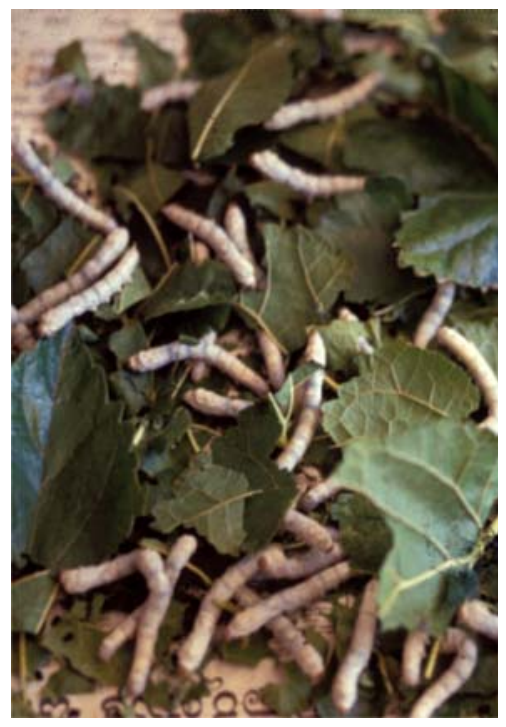

Fig 23b. Portion of tray on which tender mulberry leaves and (the nearly last instar) larvae are seen

learnt from early childhood in all the states where bamboos grow abundantly. Bamboo articles are strong but are of little weight. It was an old belief that in the rural parts of India that everyone started life in a bamboo cradle and carried on a bamboo stretcher to the funeral ground.

Bamboos are the most common material for the construction of huts (Fig. 25), houses (Fig. 


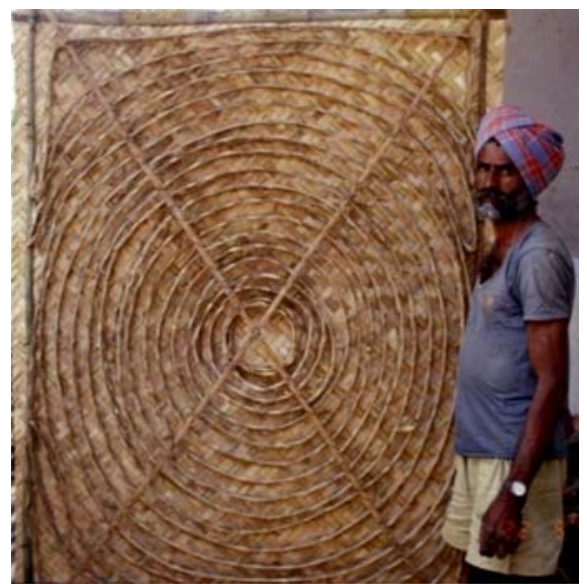

Fig 24a. Chandrike is a circular bamboo tray used for rearing mature mori silk worms into cocoons

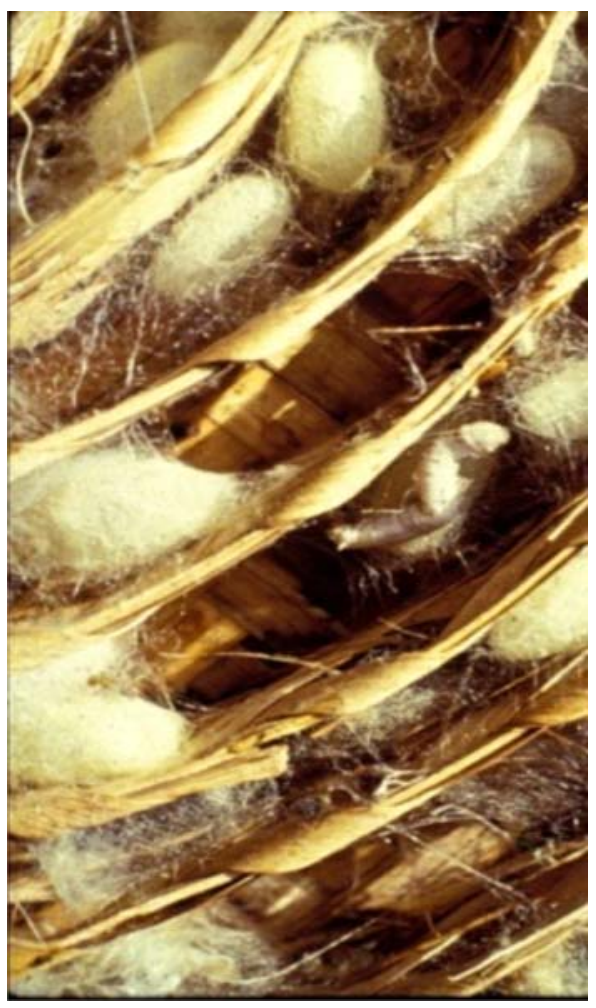

Fig 24b. Close up of Fig. 23 to show the cocoons with silk fibres

26) and pandāls (Fig. 27) in the rural areas in northeastern India and Southeast Asia.

Bamboo is used as water conduits (by breaking the nodal partitions) laying a pipeline in several developing countries. People of Arunachal

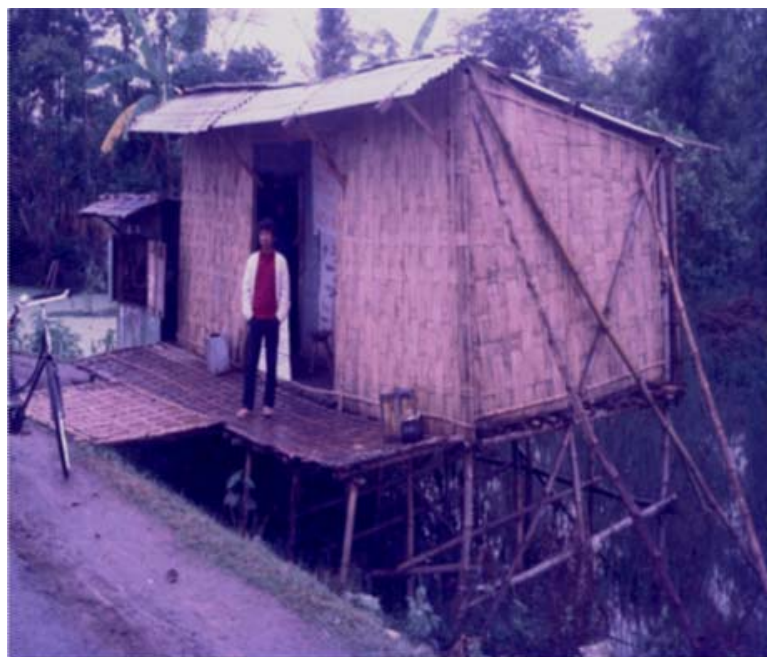

Fig 25. A hut made of bamboo on stilts near Moirang, in Manipur

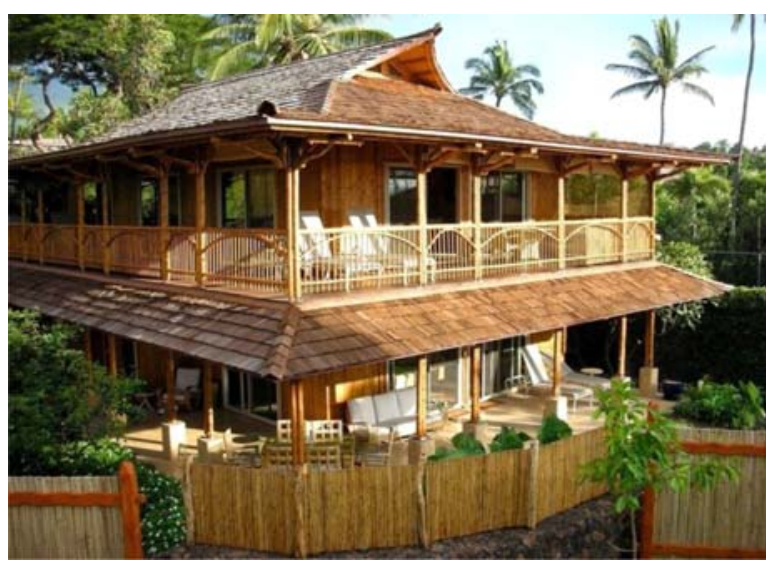

Fig 26. A modern bamboo house

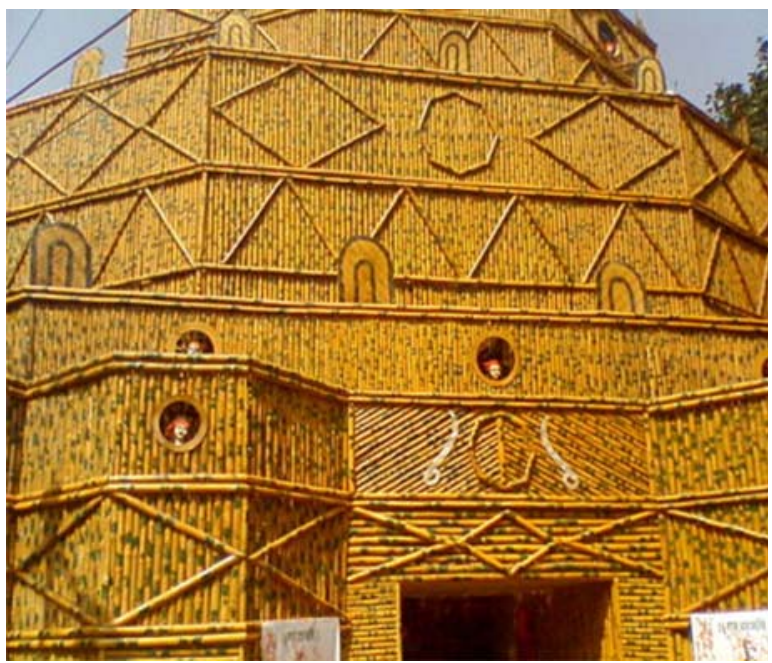

Fig 27. An artistically built Durga Pooja venue made out of bamboo material in Kolkata 
Pradesh and Mizoram use bamboos for collecting and transporting rainwater to storage tanks. It is common to see bridges across the streams. One of the most fascinating structures is the hanging bridge on the Siang River at Along, in Arunachal Pradesh. It is around $70 \mathrm{~m}$ in length and connects tribes to other hilly areas. In Northeastern parts of India, rural folk prepare bows and arrows, fish traps and as a source of fuel from bamboo.

Bamboo is a favourite material for preparing folk musical instruments. One musical instrument that is entirely made of bamboo is the Indian flute. Bansuri (the name in North India) is a very sensitive instrument. Almost all the delicate graces, curves, embellishments and shades of classical music can be expressed to perfection. In Indian mythology, bansuri is closely associated with Lord Krishna.

There are differences between the flutes used in Hindustani music (Bansuri) and Carnatic music. The late Pandit Pannalal Ghosh is to be recognized as the artist, who with single-minded devotion prepared a standard flute around $75 \mathrm{~cm}$ long with the blowing end closed, with a diameter of $2.7 \mathrm{~cm}$, with a D sharp pitch. The bamboo for making the flute must be chosen carefully and should be clean, smooth and free of cracks, holes or other damages. The best bamboos come from northeastern India, preferably Assam and Tripura. However, there is a town is U.P. near Bareilly called Pilibhit where flutes made of Dendrocalamus strictus is practised by about 500 families. A master craftsman of Delhi, Subhash Thakur, who is himself a professional flute player, designs the best quality flutes appreciated by the professionals, including the master, Pandit Hari Prasad Chaurasia (Fig. 28). The flutes used in the Carnatic Music are most probably made from Bambusa bambos. These flutes consist of a cylindrical tube closed at one end and having a cross section of $1.9 \mathrm{~cm}$. Besides the mouth hole, which is wider, there are 6 or 7 holes of the same size. In general, the length of the flute determines the pitch of the flute.

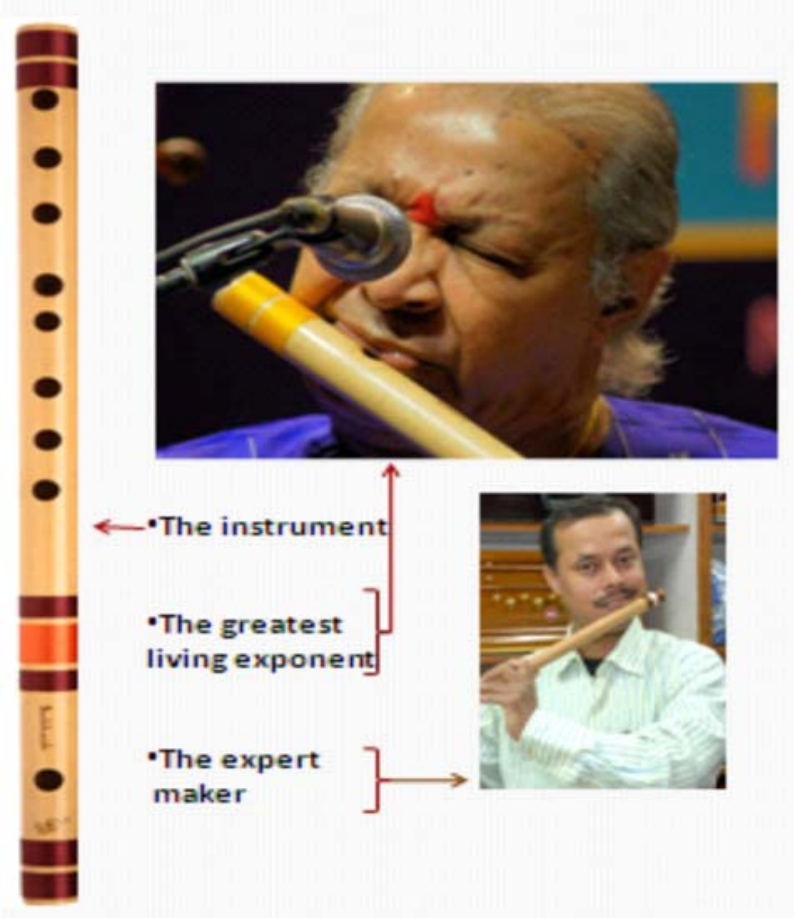

Fig 28. On the left is a flute (bansuri) used in Hindustani classical music. The lower hole is for blowing. There are eight other holes. On the top is Pandit Hariprasad Chaurasia, the greatest living exponent flautist of classical Hindustani music. On the right is Mr. Subhash Thakur from Delhi, who is an expert in preparing flutes of highest tonal quality, sold under the brand name Punam flutes. He is also an expert in playing the bansuri.

\section{BANANA}

In tracing the heritage significance of the banana (Musa spp.) it is pertinent to recall that the genus 'Musa' is named after Antonius Musa, physician to Octavius Augustus, the first emperor of Rome (63-14 BC). Arabs call banana 'mouz'. In ancient times, banana was considered 'God's gift to man'. Hence the specific epithet 'paradisiaca' (Musa $\times$ paradisiaca) was used for it (Quattrochi, 2001).

Presently, bananas and plantains (Musa spp. of the family Musaceae) are cultivated throughout the humid tropics and subtropics (Fig. 29). Whereas bananas are eaten after they are ripened, plantains are cooked and eaten as a 


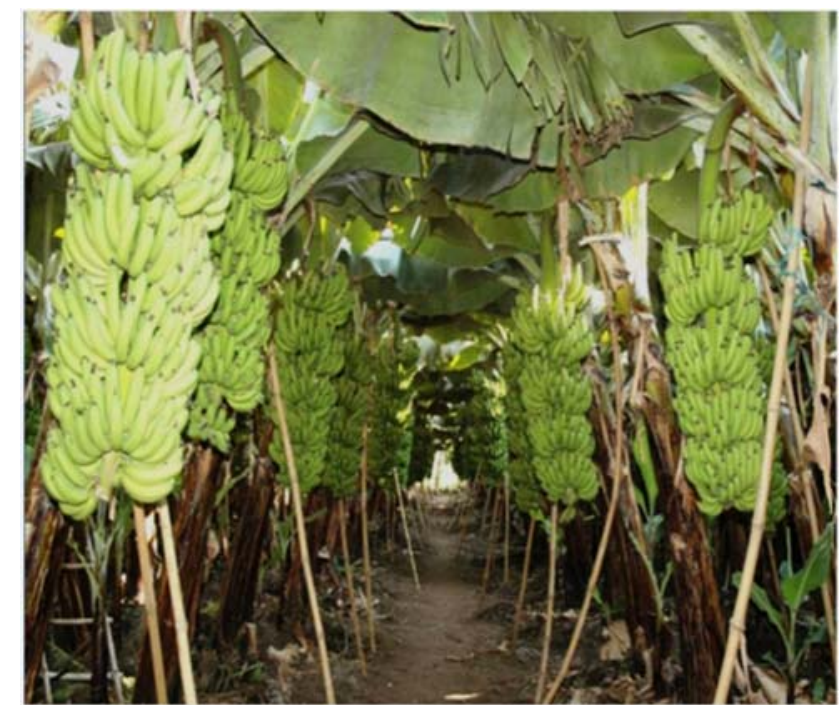

Fig. 29. Present day cultivation of banana plants, each with a heavy bunch of fruits

vegetable. The latter has a high amount of starch and little sugar. Harvested when full and green and are cooked, or sliced and deep fried to make chips (like potato chips) and consumed. The highly rated banana chips made of 'nendran' banana come from Kozhikode (Calicut). There is evidence that cultivated bananas and plantains originated in Southeast Asia and the Western Pacific. Subsequently, these were introduced into Africa in ancient times and then carried by European explorers to the Americas and other parts of the world (Denham et al., 2009). All the edible Musa spp. are believed to have originated from two wild species -Musa acuminata Colla and M. balbisiana Colla, containing A and B genomes respectively. Over 1,000 recognizable Musa cultivars have been identified so far (Denham et al., 2009). The taxonomy of Musa remains unresolved at the sectional, specific, and infraspecific levels. Explorations have resulted in the discovery and description of many new species and varieties the most recent being $M$. indadamansesis from Andaman and Nicobar islands (Singh, 2014) and M. nanensis from Thailand (Swangpol et al., 2015) leading to reclassification of the taxa. Presently bananas and plantains are grown in over 150 countries. The top five countries in the world are: India (24.87 million MT), China (10.55 million MT), Philippines (9.23 million MT), Ecuador (7.01 million MT) and Brazil (6.9 million MT) (Agrawal and Tyagi, 2014).

The antiquity of banana in India can be judged by its reference in classical literature such as Rāmāyana (2020 BC), Kautilya's Arthaśāstra (350-272 BC) and its depiction in the historic caves of Ajanta and Ellora. For people in the western world bananas are merely a dessert fruit. For Indians, particularly in the southern and eastern parts, banana symbolizes fertility, prosperity and veneration. In the Chennakesava temple in Somanathapura, Mysuru, built in Hoysala architectural style in 1268 AD (748 years ago), the tip of a banana bunch has been carved in the ceiling (Fig. 30).

The other uses of Musa spp. are as follows: fibre, ornamentals, and disposable platters. Leaves molded by heat into cups and plates are commonly

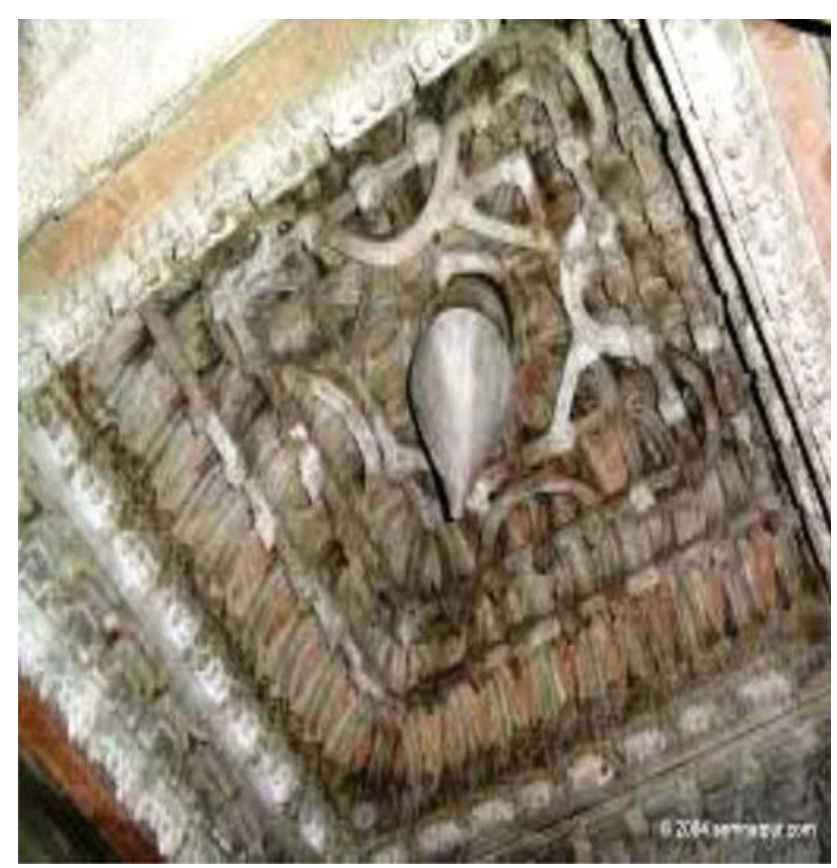

Fig. 30. A picture of ceiling taken from Chennakesava temple showing the tip of a banana bunch in Somanathapura, Mysuru. This temple is one of the finest examples of Hoysala architecture built in 1268 AD (748 years ago) 
used for large-scale catering. In many parts of south India, a pair of fruit-bearing banana stems is tied at the entrance for decorating homes and venues of weddings, as an auspicious symbol. Owing to so many useful qualities, the banana plant has received the honorific 'Kalpataru'.

India is home to more than 100 named cultivars/landraces, although only 15-20 have attained commercial importance. The 'Hill Bananas', endemic to Palani Hills of Tamil Nadu are famous for their unique aroma and flavour. Their reputation is so high that in 2008, two cultivars, 'Virupakshi' and 'Sirumalai', each received a Geographic Indication designation based on the interaction between the cultivars and the environment in which they grow. Over the past decades, however, Hill Bananas are succumbing to bunchy top, a devastating viral disease. The banana farmers have taken steps to manage the disease with the help of scientists through Tamil Nadu Hill Banana Growers’ Federation (http:// www.virupakshi.org/index.php/en/geographicalindication). The major banana growing states in India are Maharashtra, Tamil Nadu, Karnataka and Gujarat. There are many other interesting landraces such as 'Nanjangud rasabale' (named after a unique town near Mysore city, with a taste highly rated among the connoisseurs) closely interwoven with the traditional heritage of India needing immediate attention for their documentation and conservation (Uma et al., 2014). The varieties that are currently popular in India are Cavendish 57\%, Poovan 16\%, Bluggoe $7 \%$, Nendran 5\%, Pome 4\%, Rasthali 3\%, others 8\%, (Fig. 31, 32).

\section{Coconut}

The coconut palm (Cocos nucifera L.) is perhaps the world's most bountiful plant. It has a straight trunk sometimes reaching up to $25 \mathrm{~m}$ (some varieties are dwarf) and bearing a crown of 25-30 pinnately compound leaves, each bearing 200-250 leaflets (Fig. 33). Every part of the palm

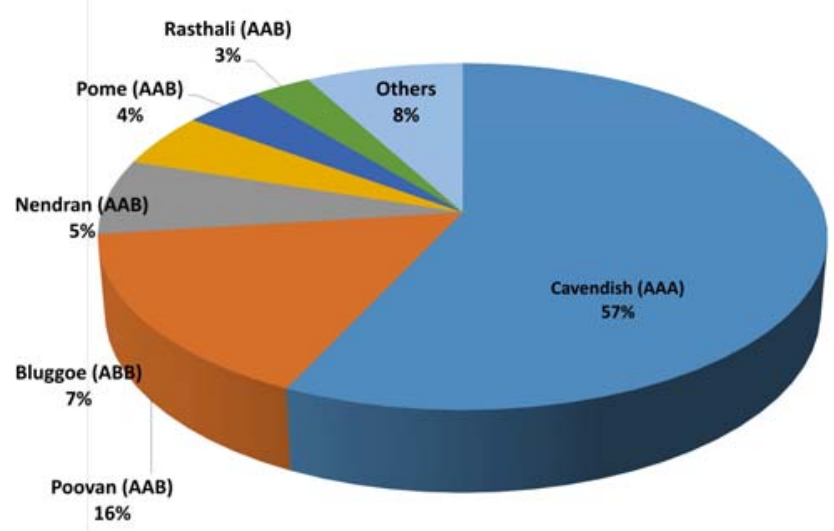

Fig 31. A diagrammatic representation of six varieties of triploid banana with $\mathrm{A}$ and $\mathrm{B}$ genomes
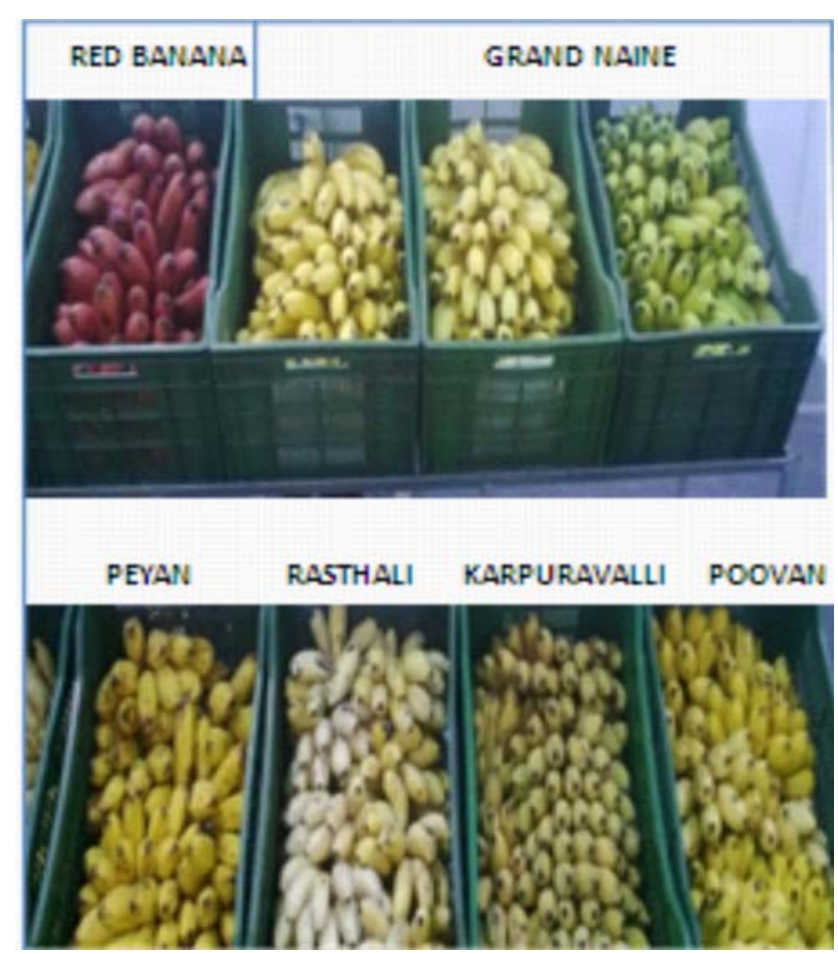

Fig 32. Diversity of edible bananas grown in India

is beneficial. There is some disagreement about the exact region of origin of the coconut palm. It is believed to be a native of Malaysia and surrounding regions. These palms flourish along the coastal regions of all tropical seas around the world, as well as in the interior regions.

Botanically, coconut fruit is a drupe (oviod to irregularly globose, up to $30 \mathrm{~cm}$ long, green, yellow or brown with a densely fibrous mesocarp 


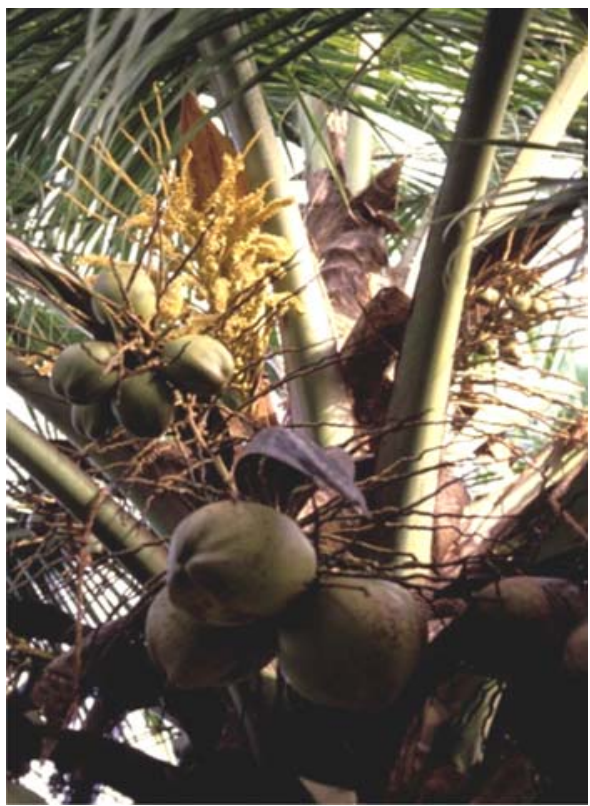

Fig. 33. A coconut palm with bunches of fruits

and a stony endocarp that encloses a single large seed (Renuka and Sreekumar, 2012). The seed is unique as it is the only seed that contains a copious amount of liquid (endosperm) — coconut water. As the seed matures the peripheral part of the endosperm develops a thick white solid flesh (meat) (Fig. 34), leaving behind a small amount of liquid. It is at this stage that the fruit is dehusked and sold. The thick white liquid squeezed out of the grated coconut meat is coconut milk, used for cooking various dishes. When the whole coconut is dried in the sun, the brown coloured seed separates out. It is called copra. It is pressed to obtain a thin liquid- the coconut oil. It is widely used for cooking, as hair oil, and for moisturizing the skin. Other major products of the oil are soaps and cosmetics.

The whole leaf is an ideal material for making temporary sheds and thatching. The leaflets are used for preparing brooms, baskets, mats, and cooking skewers. Coir is extracted from the fibrous husk and charcoal is made from the hard shell. Coir is used as a good decorative material and for preparing ropes (Figs. 38 \& 39).The latter used for drawing water from wells
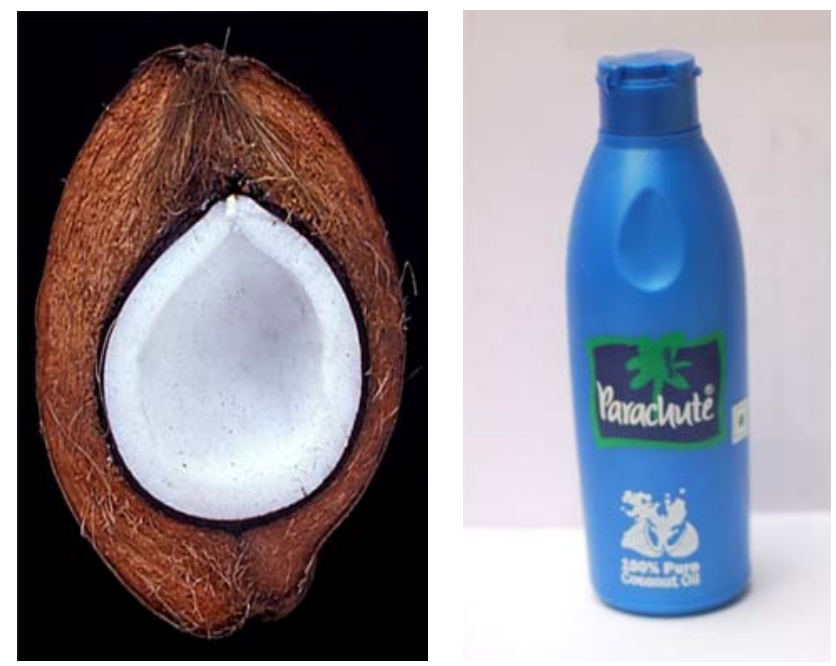

Fig. 34. A vertical section through the fruit showing the fibrous mesocarp, stony endocarp and fleshy seed in the middle, the thick white portion representing solid endosperm. The embryo is seen as a small projection at the top of the seed (left)

Fig. 35. Plastic bottle containing coconut oil (right)

and by fishermen, especially because coir ropes do not rot in sea water. Whole coconuts are shaped into decorative objects (Fig. 38).Coir is a material of choice for floor mats, doormats, brushes, sacks, fishing nets, caulking for boats, and for stuffing mattresses and sofas. It is powdered and used in potting compost in horticulture. Coconut shells could be employed as bowls and ladles, and are also used in preparing buttons and decorative articles and shell- craft necklaces (Fig. 40). Charcoal bricks are used for cooking. Coconut trunks are often employed for building houses, huts and small bridges (laid across narrow canals); they are preferred over other materials on account of their straightness, strength, and salt resistance. The roots yeild a dye, a mouthwash, and medicine for diarrohea and dysentery. A frayed piece of root serves as a toothbrush. When the whole coconut is cut into half and dried in the sun, cup copra separates out leaving the half shell empty. That part is nailed on to a rubber tree trunk to collect the latex after tapping.

Coconut (Sanskrit: nārikela) is an essential element of rituals in Hindu tradition. Vedas do not 
mention the coconut. It could not have been growing in the northwestern parts of the Indian sub-continent where Vedas were believed to have been composed around 1500 BC. Therefore, narikela appears to be a relatively a recent term.

Coconut is offered during worship of a Hindu god or goddess. Coconut flowers are auspicious symbols in Hindu and Buddhist weddings and other important occasions. The inflorescence branches bearing flowers are inserted into a barrel-shaped measuring vessel (para in Malayalam) filled with unhusked rice (paddy) and placed during wedding ceremony and other auspicious occasions in Kerala. Breaking of a dehusked coconut is also a common practice on important and religious occasions in and temples in many parts of India.

Chopping the tip of the tender coconut and sipping the water with a straw has long been a low cost refreshment in tropical countries (Fig. 36). Water of the tender coconut is completely sterile, contains abundant vitamins and minerals, and has the same balance of salts as the human blood (isotonic). It is used in oral rehydration therapy in patients especially suffering from gastrointestinal disorders resulting in acute dehydration.

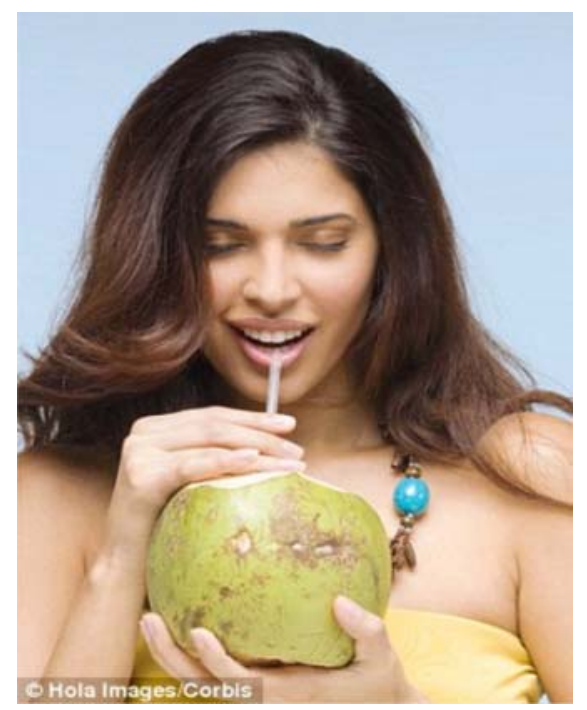

Fig. 36. A young lady drinking coconut water from the opened tender fruit with a straw.

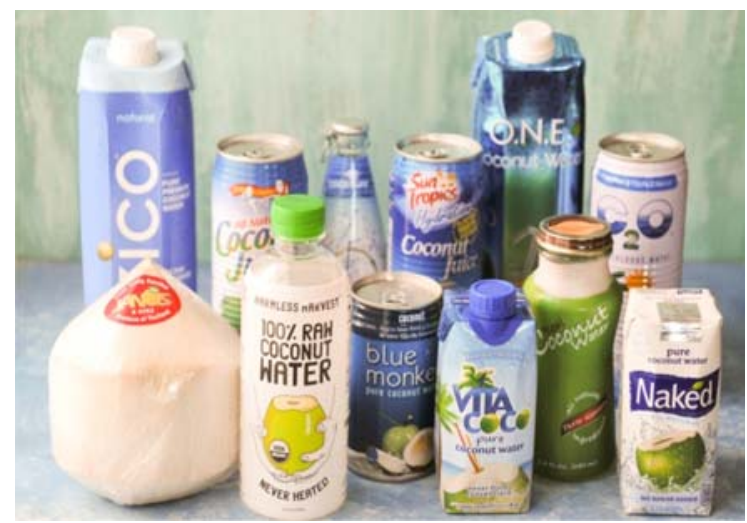

Fig. 37. Some brands of commercially sold coconut water

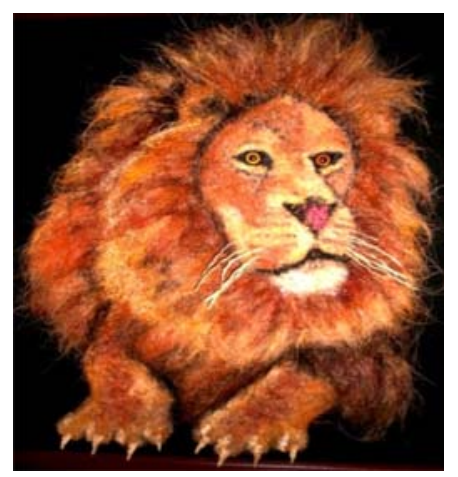

Fig. 38. An elegantly crafted lion's head from coir and other materials

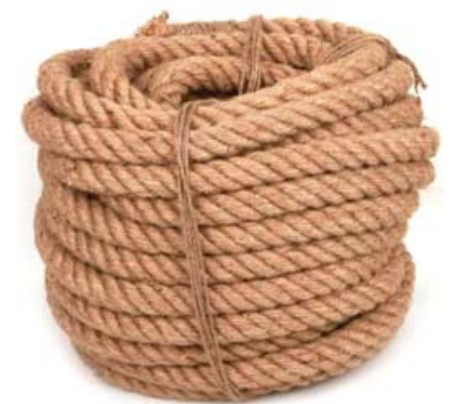

Fig. 39. A bundle of thick coir ropes

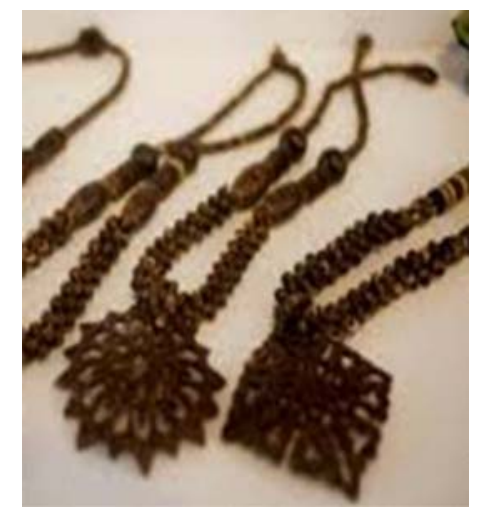

Fig. 40. Coconut shell-craft necklaces. 
First commercially used as a fizzy sports drink in Rio de Janeiro (Brazil), the bottled coconut water has now been developed into a US \$1 Billion industry all over the world (https:// transferwise.com/blog/2014-05/why-coconutwater-is-now-a-1-billion-industry/). The largest non-alcoholic company in the world, The CocaCola Company (TCCC) USA started selling coconut water in Tetra Pak (Fig. 37). There are over 100 brands of coconut water (including Dabur) and over 250 companies have beverages with some coconut water in them. Coconut water is a prized addition to many alcoholic beverages such as the popular pina colada. It is a flavouring agent for rum. Coconut water taken out of the fruit ferments rather quickly and has to be made into wine or vinegar.

\section{Black Pepper}

Black pepper (Piper nigrum L.) is regarded as the king of spices. It is native to southwestern Ghats of India. It was one of the earliest commodities to be traded in the world. It was in great demand in Europe as meat stored in winters was unpalatable and black pepper significantly improved its taste. The early Romans got access to the Malabar Coast in India and its range of exotic spices after their conquest of Egypt in 30 $\mathrm{BC}$. The price of pepper was extremely high in the Middle Ages and the traders considered black pepper as ' gold'. It was used as currency in the Middle Ages and the term 'as dear as pepper' was used for anything very expensive. In the mid $15^{\text {th }}$ century Portugal was the leading nation of all of Europe. It sent Vasco da Gama (1460-1524) explorer to sail to the west coast of India (Fig. 41). He was the first person to reach India by sea, landing in Calicut (Kozhikode) in 1498, linking Europe and Asia via the Cape of Good Hope (Figs. 42, 43).

Black pepper is a perennial crop in the tropics and is the most important and highly sought after spice crop of the world. It is not only a

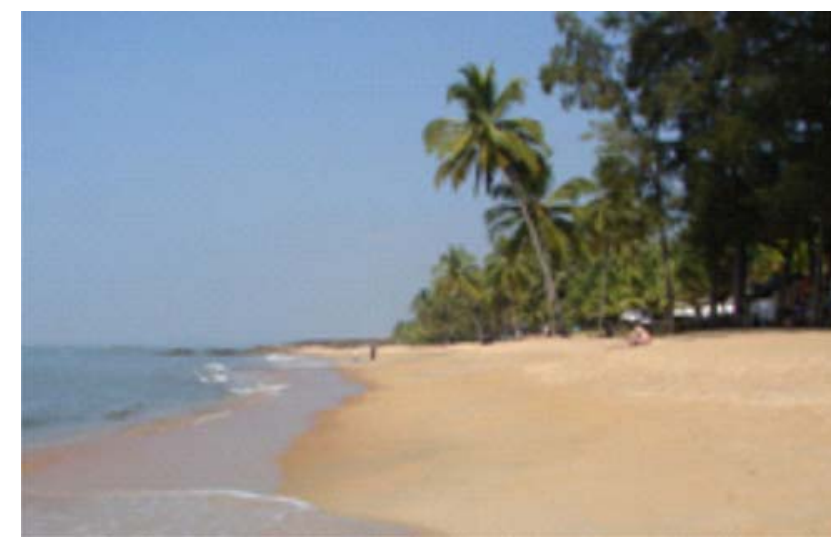

Fig. 41. Seacoast along Arabian Sea in Calicut

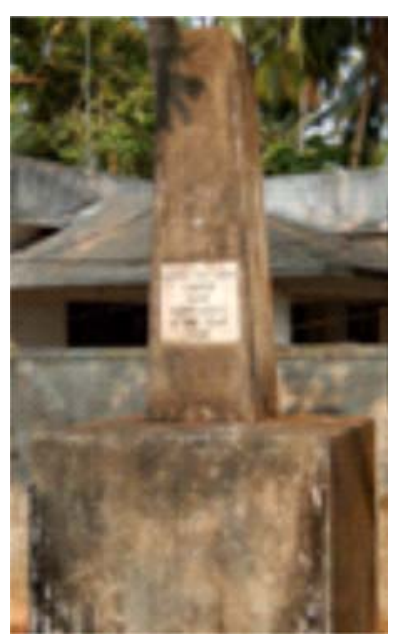

Fig. 42. A monument mentioning the place where Vasco da Gama arrived

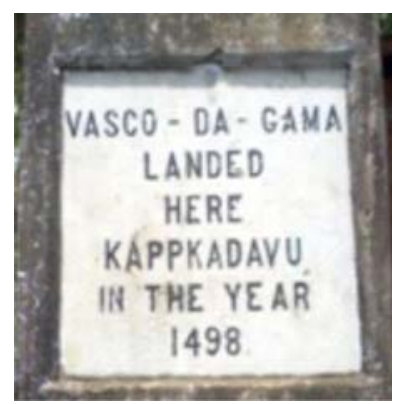

Fig. 43. The plaque enlarged from the monument to indicate that Vasco da Gama arrived at Kappakadavu

flavouring agent but has medicinal properties. Black pepper is considered to have originated in the hills of Southwestern Ghats of India. It is now also grown in Indonesia, Malaysia, Sri Lanka, Thailand, China, Vietnam, Cambodia and has been 
introduced to the New World countries such as Brazil, Mexico and Guatemala.

For centuries, India was the main producer of black pepper. As of 2008, Vietnam is now the world's largest grower and exporter of black pepper, accounting for 34\% of the total production. Surprisingly India which was the top exporter till 1995 has turned a net importer of the spice in the last calendar year (http://www.businessstandard.com).

There are over 75 cultivars of black pepper in India alone, which vary in oleoresin and piperine content. Presently, Kerala, Karnataka and Tamil Nadu are the top three pepper producing states in India.

The black pepper plant grows as a vine reaching up to $10 \mathrm{~m}$ in length trailing on the support of tall trees. It thrives best in loamy, red 'laterite' soil, which is found along the Malabar Coast in the Western Ghats region. Fruits are borne on long spikes, each containing 50-70 spherical fruits. Harvesting begins when the berries at the base of the spike start turning red (Fig. 44). The fruits in Kerala are dried on a clean cloth spread in the sun along roadsides (Fig. 45). The premium

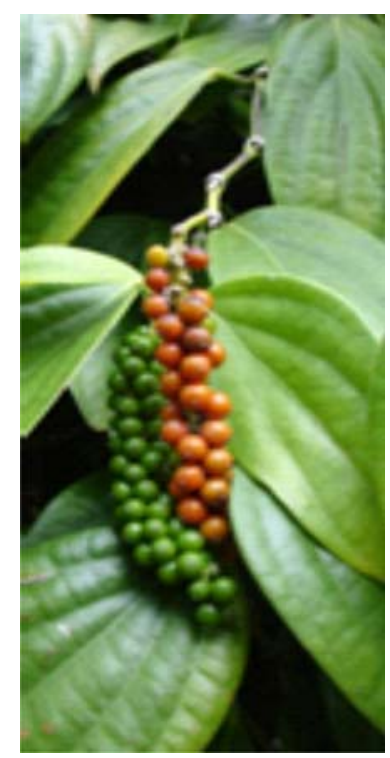

Fig. 44. Green and reddish-orange fruiting spikes of black pepper

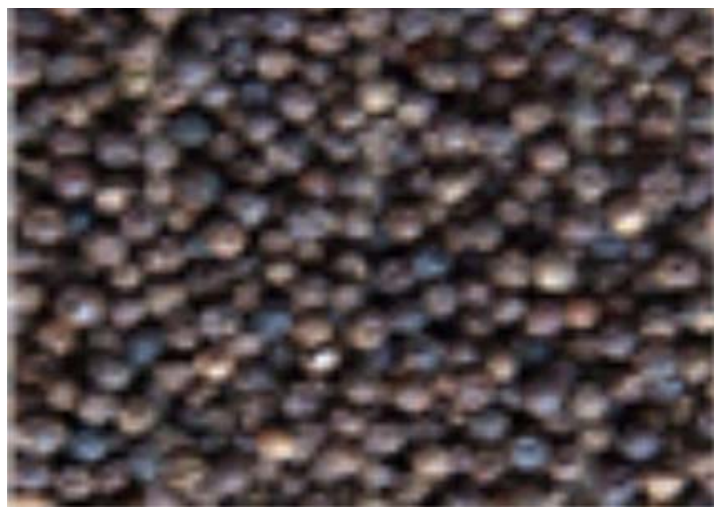

Fig. 45. Sun dried black pepper

Indian varieties are Tellicherry pepper and Malabar pepper. Malabar Garbled variety is known as the world's best black pepper. Karimunda is the most popular cultivar in Kerala. In terms of quality, Kottanadan has the highest oleoresin (17.8\%) content followed by Aimpiriyan (15.7\%). The special flavour (heat) in black pepper is attributed to the active ingredient piperine. It triggers taste buds and regulates the digestive processes. It improves appetite, prevents cough, cold, dyspnoea and reduces inflammation of the throat. It has antipyretic and analgesic properties also. Black pepper prevents water retention problems by promoting sweating as well as urination. It helps in better absorption of curcumin from turmeric and beta-carotene, selenium and vitamin B.

\section{Cardamom}

Cardamom (chhoti ilaichi )Ellettaria cardamomum (L.) Maton, (Family Zingiberaceae) is also known by the name lesser cardamom of commerce. The greater cardamom or Bengal cardamom (badi ilaichi) is Amomum aromaticum of commerce. Lesser cardamom bears ripe fruits (capsules) which are light green coloured (Fig. 47). It is often referred to as the 'Queen of Spices' on account of the exquisitely pleasant aroma and taste of the seeds. It is native to the forests of the Western Ghats in southern India, where it grows wild (Fig. 46). The deep brownish black seeds 


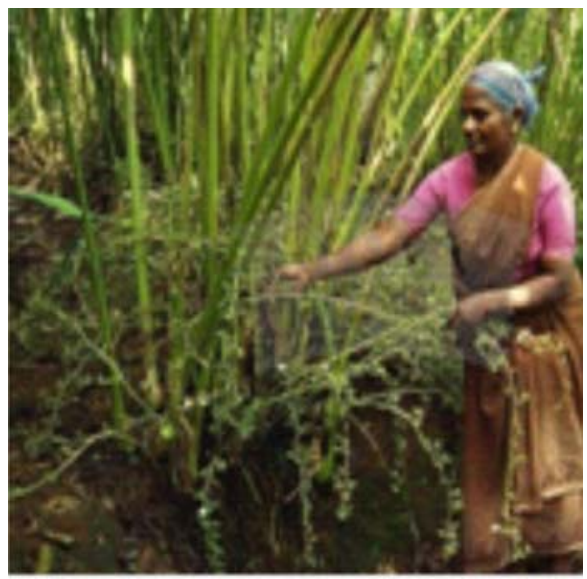

Fig. 46. A woman harvesting the green cardamom fruits

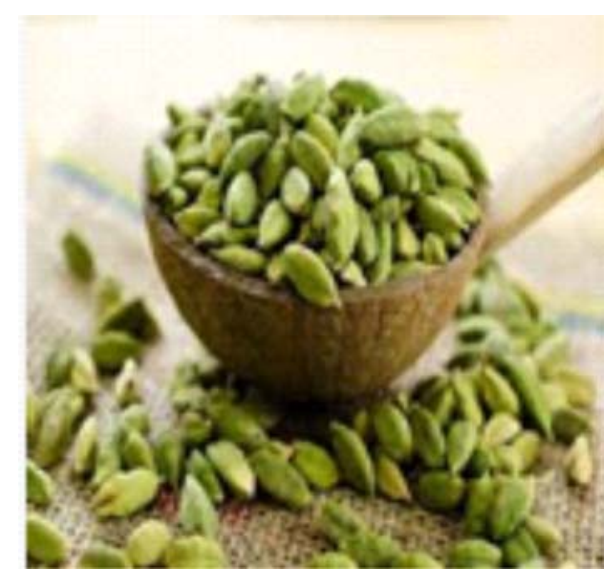

Fig. 47. A coconut ladle full of cardamom fruits

contain a highly fragrant essential oil with several medicinal as well as flavour containing compounds. The seeds are also rich in minerals especially potassium, calcium, magnesium and phosphorous. Cardamom is a perennial, herbaceous, rhizomatous plant, cultivated in the areas close to Western Ghats of India. Presently cardamom is a commercial crop in Guatemala and grown on small scale in Tanzania, Sri Lanka, El Salvador, Vietnam, Laos, Thailand, Cambodia, Honduras, and Papua \& New Guinea. India used to be the leading exporter of cardamom. The major use of cardamom abroad is in the preparation of ' $g a h w a$ ' - a strong cardamom coffee concoction which is a symbol of hospitality among the Arabs. In Asia, it can add a lingering sparkle to any kind of food item in traditional as well as modern dishes (both sweet and hot). In Scandinavian countries, cardamom finds a prominent place in baked goods and confectionery.

In Europe and North America, it is an ingredient in curry powder and in some sausage products. Cardamom oil and oleoresin have applications in flavouring processed foods, cordials, and liqueurs, in perfumery, and in Ayurvedic medicines.

\section{Turmeric}

Often referred to as 'living gold' or 'one plant drugstore', it is the dried rhizome of Curcuma longa L., a member of the family Zingiberaceae (Fig. 48). Whereas details about the origin of turmeric are not clear, it is widely believed that it is a native of South East Asia or South Asia, where it is still grown abundantly. In India, turmeric has been grown since time immemorial, holding an important place among the spices and for its proven therapeutic properties. Its vivid, fast yellow colour made it an important dyeing agent in ancient times and it is once again gaining popularity as a vegetable dye in today's ethnic apparel industry. India is the largest producer, consumer and exporter of turmeric in the world. The important turmeric growing States in India are Andhra Pradesh, Tamil Nadu, Orissa, Maharashtra, Assam, Kerala, Karnataka and West Bengal of which Andhra Pradesh and Telangana occupy 40 per cent of the total cultivation area. Indian turmeric is considered the best in the world market because of its high curcumin content (Figs. $49,50)$. India accounts for about 80 per cent of world turmeric production and 60 per cent of world exports. Other major producers are Pakistan, China, Haiti, Jamaica, Peru, Taiwan and Thailand. Asian countries consume much of their turmeric production.

Some of the most popular varieties of turmeric in India are kasturi, mundaga, balaga, lokahandi. Lakadong is a much sought after 


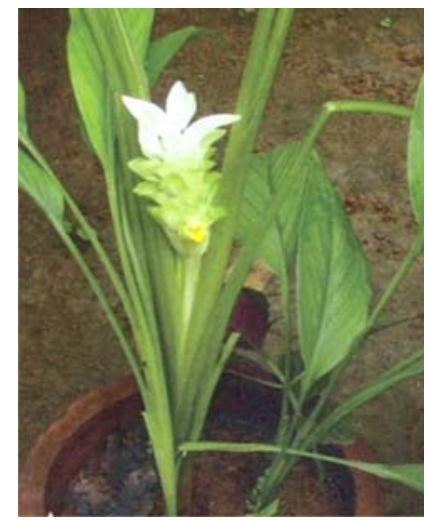

Fig. 48. A potted plant of curcuma to show the aerial part

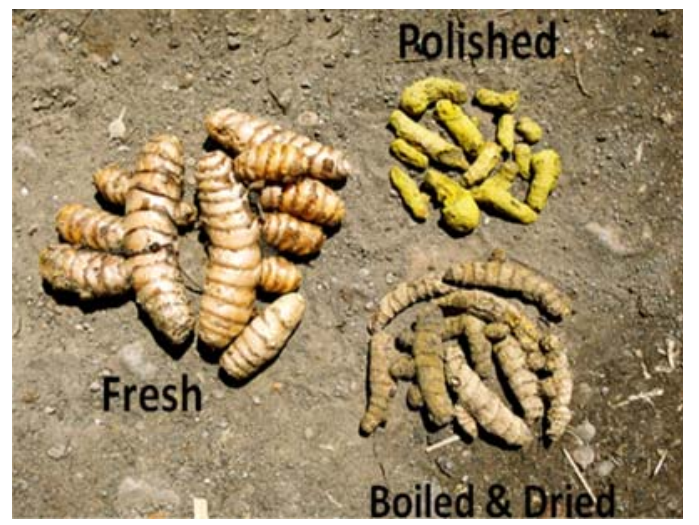

Fig. 49. Fresh and polished, boiled and dried rhizomes variety by the extraction industry because of its high curcumin content. It is a location specific variety grown in Meghalaya. It grows in a small region in the West Jaintia Hills district. The curcumin content of Lakadong turmeric is between 6 to $7 \%$, which is the highest, as against a mere 2 to $3 \%$ in most varieties. Geographical Indications (GI) tag registration had been obtained for Lakadong turmeric, which is known to have high medicinal qualities (Spices Board of India).

Turmeric is used in cooking various dishes and curries such as rasam, sambar, kadi, haldi ki subzi. Mustard and turmeric pastes are often used for the preparation of meat and fish items.

Since ages, turmeric and sandalwood paste, called uptan or ubtan, has been used in India for application on the skin. It is an effective exfoliating treatment, which tones the skin, removes wrinkles and dark circles under the eyes. It is a traditional way to treat skin diseases and make it glow. Ayurveda lists many plants for skin care such as a paste of turmeric, sandalwood, chickpea flour, nuts, flowers and mustard oil. It is applied to the bride and the groom as part of the haldi ceremony just before the wedding to give them fresh glowing skins and to ward off the evil eye (Fig. 51). Research has found that ubtan not only enhances the appearance but also has definite antifungal, antibacterial and antiperspirant properties.

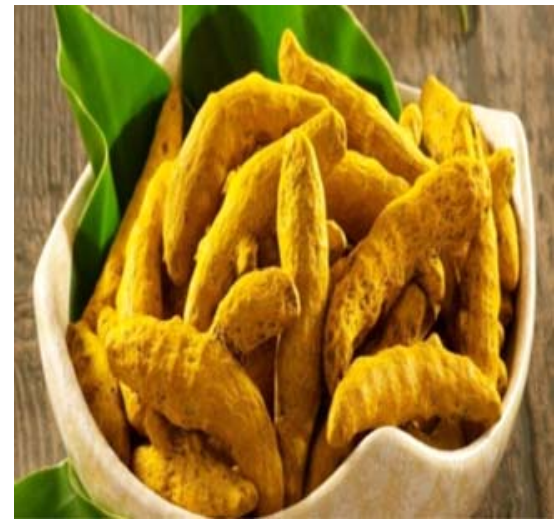

Fig. 50. A bowl containing commercial sample of dried turmeric sold in the market

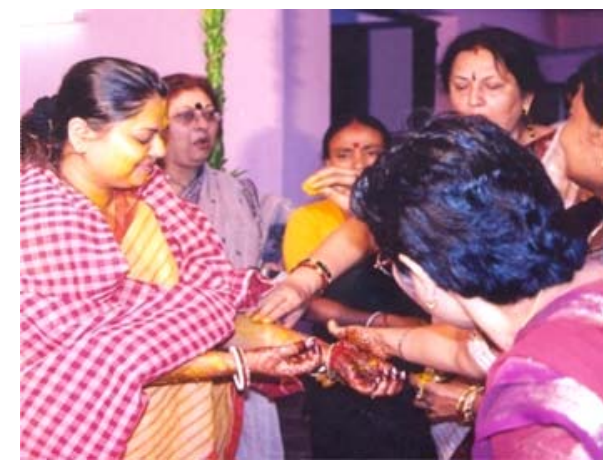

Fig. 51. Application of Ubtan during a traditional Bengali wedding ceremony of the bride

In India, turmeric has been used in an attempt to treat stomach and liver ailments, as well as topically to heal sores because of its antimicrobial property. The active compound curcumin is believed to have a wide range of biological effects including anti-inflammatory, antioxidant, antitumour, antibacterial, and antiviral activities. Turmeric is also used for the treatment of mastitis in cattle. Mastitis is a bacterial infection leading to swelling of the udder and teats and causing severe pain in milch cattle and can be treated with prolonged use of antibiotics. However, milk consumed by humans from such cows can cause a build up antibiotics in their body. Dr. M.N.B Nair working in FRLHT (Foundation for Revitalization of Local Health Traditions), Bengaluru has reported that a paste 
of turmeric and calcium hydroxide $\left[\mathrm{Ca}(\mathrm{OH})_{2}\right]$ application is effective in curing mastitis. He has participated in several international conferences and discussions on veterinary medicine to spread this traditional knowledge, which has been tested and found beneficial.

\section{0. $\bar{A} M L \bar{A}$}

Oonla or Indian Gooseberry (Emblica officinalis Gaertn.) is a medium sized (8-18 m high) deciduous tree of the family Phyllanthaceae. The edible fruits are highly valued for their medicinal properties. The leaves are simple, sub-sessile and closely set along branchlets, resembling pinnately compound leaves. The flowers are borne in the axils and develop into spherical, light greenish yellow fruits. The size of the fruit varies from small marbles to small lemons (Fig. 52). A variety with larger fruits is popular in Varanasi. When the fleshy part is removed, the inner hard covering reveals six radial ridges (Fig. 53), and a short persistent style - a symbol embodied in Hindu temple architecture (Āmalaka below the Kalasha) (Fig. 54). Generally, the number of ridges in the architectural amalaka is higher. There is a celebration of the āmalaka tree known as Āmalaka $E k \bar{a}$ daśi -a holy day in the lunar month of phālguna (February- March) when prayers are offered to the tree. It heralds the beginning of the Holi festival.
$\bar{A} m l \bar{a}$ fruit is slightly astringent but creates sweetness of the mouth after sipping some water! $\bar{A} m l \bar{a}$ was believed to be a rich source of vitamin C. There is some recent doubt about the vitamin $\mathrm{C}$ content as it is highly variable. However, there is positive agreement that it is a rich source of antioxidants. $\bar{A} m l \bar{a}$ is one of the ingredients of Triphala in Āyurveda with harad (Terminalia chebula) and baheḍa (Terminalia bellirica). $\bar{A} m l \bar{a}$ is eaten in pickles or cut into pieces and dried in ginger juice or boiled and soaked in sugar candy (murabba). Ámla is used in the preparation of traditional hair dyes and shampoos. Fruits, bark and leaves of triphala plants are rich in tannin. The wood of the amla tree finds use in preparing agricultural implements, poles and inferior quality furniture.

\section{TAMARIND}

Tamarindus indica L. (family Leguminoseae) is indigenous to tropical Africa but must have been introduced to India a long time ago. It is a magnificent tree (Fig. 55) that is long-lived and bearing an abundant number of flower buds and pods (Fig. 56, 57). The acidic pulp in the pods is rich in vitamin $\mathrm{C}$, protein, tartaric, malic and citric acids. It is extensively used in cuisines as a souring agent in preparing refreshing drinks, chutneys, sauces and an important ingredient of
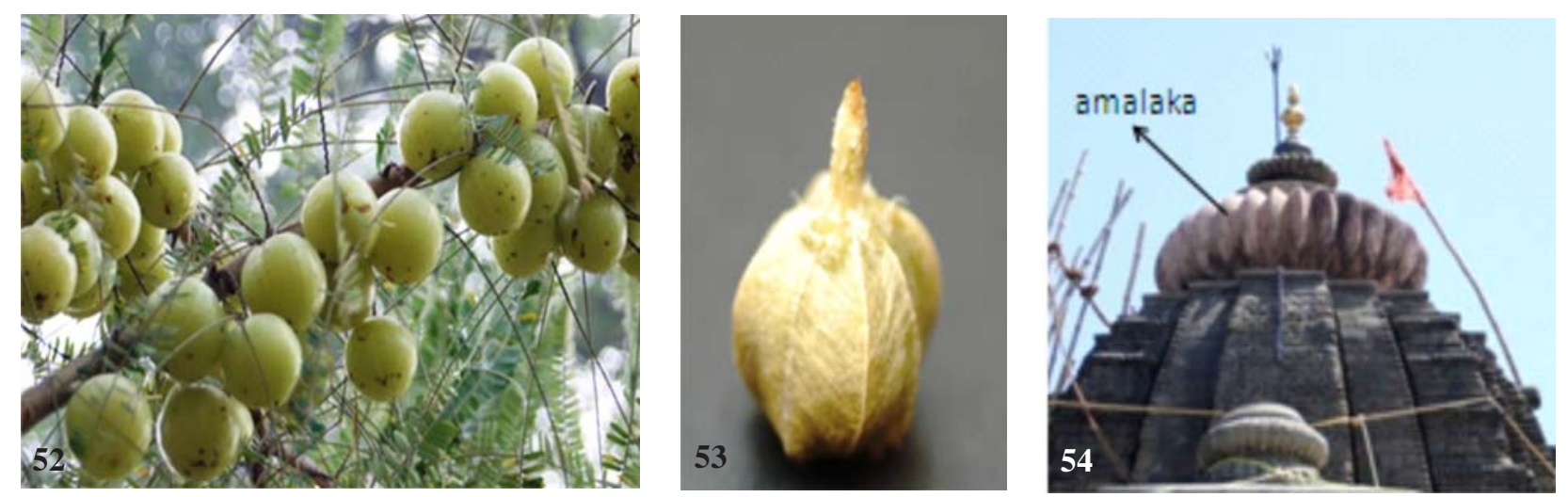

Figs. 52-54. 52. A bunch of fruits of Āmlā (Emblica officinalis) on a branch of the tree. 53. A fruit from which fleshy part has been removed to show the prominent ridges and the persistent style and stigma. 54. A stylized Āmalaka from the top of a Hindu Temple (under repairs) showing many ridges. 


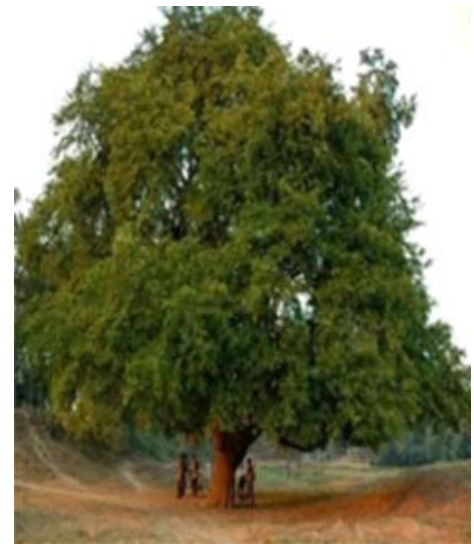

Fig. 55. A large tamarind tree

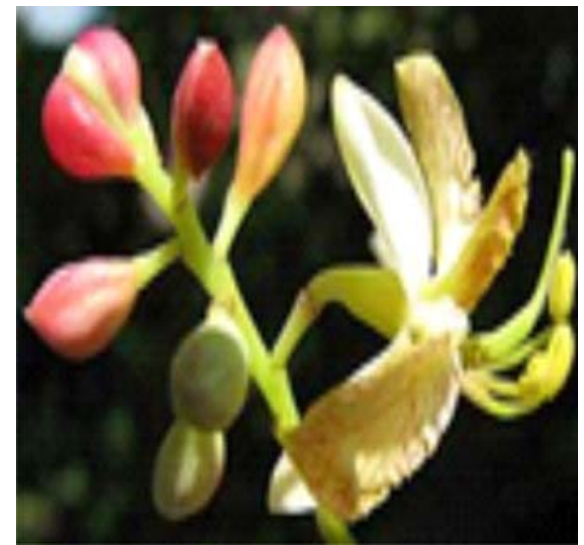

Fig. 56. A twig with open flower and flower buds.

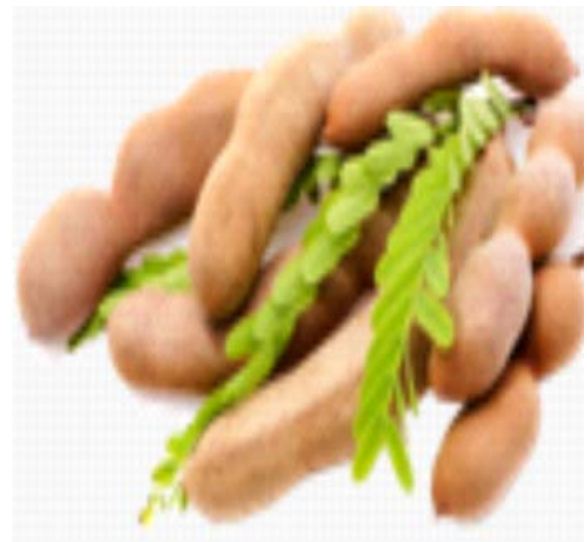

Fig. 57. Mature pods with a few leaves south Indian culinary preparations such as rasam and sāmbar (Fig. 58, 59, 60). Tamarind intake is reported to delay the progression of skeletal fluorosis by enhancing urinary excretion of fluoride. furniture, decorating planks for paneling and as a substitute for teak and sāl. The wood produces a high quality charcoal for making jewellery, because the heat produced by burning charcoal is the highest among plants i.e. (7800 J). Further,

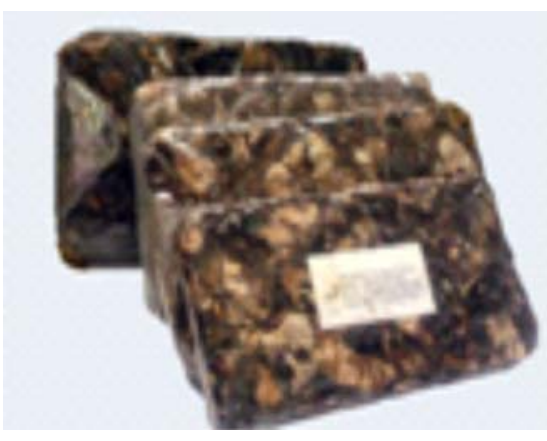

Fig. 58. Packets of processed tamarind pulp available in the markets

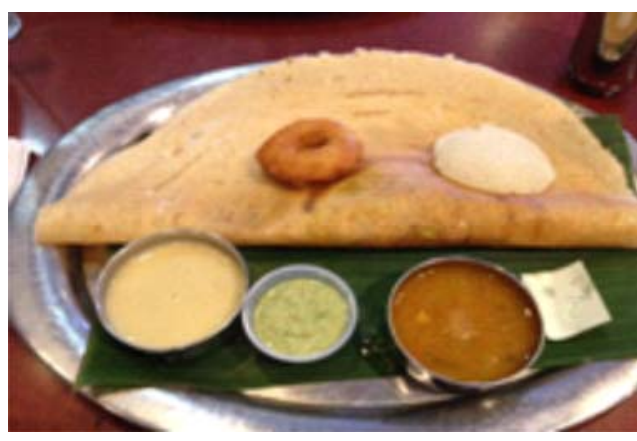

Fig. 59. A typical south Indian thālì with dosā, idlī, vadā and little plates of sāmbar (extreme right) and chutneys all spread on a piece of a banana leaf
Tamarind seeds are shiny and chocolate brown in colour and were used in indoor games and teaching counting to children in rural southern India. The pulp is also used for polishing brass shrines, statues, lamps and copper, brass, and bronze utensils. Roasted and ground powder is an adulterant of coffee. Rich in pectin, tamarind is exported from India for the manufacture of plywood.

Tamarind wood is used in construction work, in agricultural implements, for wood blocks, charcoal fire is long-lived, tar less and nonsparking, non-smoking with low ash content and no dust.

\section{NEEM}

Nìm, neem, or margosa (Azhadirachta indica A. Juss.) one of the most useful trees grown in India (Fig. 61), is probably a native of Myanmar. There are no forests in India where neem grows wild. It is extensively cultivated in the Old World tropics. In India it thrives even in semi-arid regions 


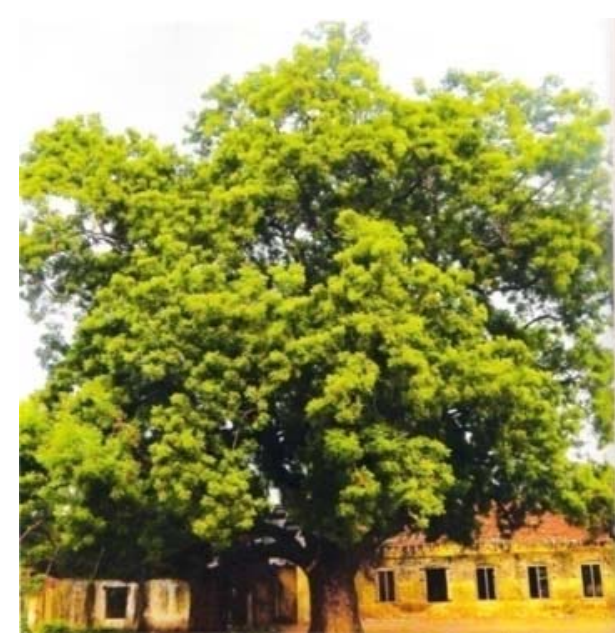

Fig. 61. A large neem tree (courtesy- Nizhal, Chennai)

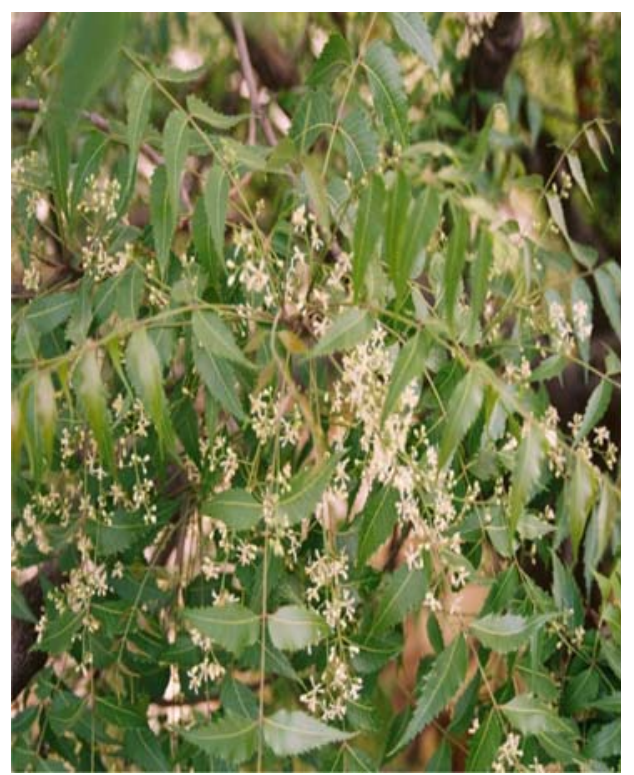

Fig. 62. Twig full of compound leaves and flowers

of Rajasthan and Gujarat. The leaves (Fig. 62) are bitter and yield azhadirachtin, the most potent naturally occurring insect anti-feedant compound. In parts of Karnataka, Andhra and Telangana, the tender leaves of neem and jaggery are mixed and eaten on the New Year's Day (Ugādi festival) to signify that throughout the year sweet and bitter things be accepted with equanimity. Neem is a shade tree. 50,000 trees have been planted in the plains of Saudi Arabia to help shield a camp of over 2 M Muslim Hajj pilgrims. Rural people and the traditional societies in urban areas still use the cut twigs of neem as disposable chew sticks to clean their teeth (Fig.65, 66). Wood from neem is used for cooking and heating.

The famous Jagannātha temple (Fig. 63) in the holy city of Puri in Odisha contains idols of Balabhadra, Subhadrā and Jagannātha made out of neem wood (Fig. 64). The images of these gods are replaced after 12 or 19 years in a ceremony called Nabakalebara ('Naba' means new and 'Kalebara' is body). The spirit from the old idols is transferred to the new idols and the former are kept in the basement of the temple. There is an

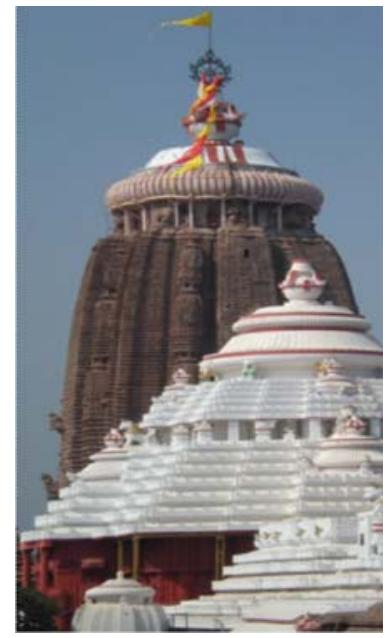

Fig. 63. The famous Jagannātha temple of Puri

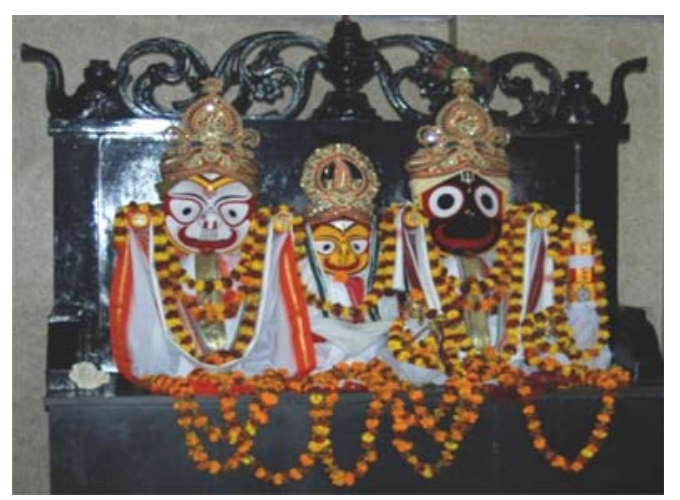

Fig 64. The decorated idols of Balabhadra, Subhadrā and Jagannātha (L-R) made of neem wood, notice that idol of Lord Jagannātha has circular eyes and black face, and Balabhadra and Subhadrā have slant eyes with small eye balls. Idol of Subhadrā is painted yellow and Balabhadra is painted white. (See the text for details of Nabakalebara) 


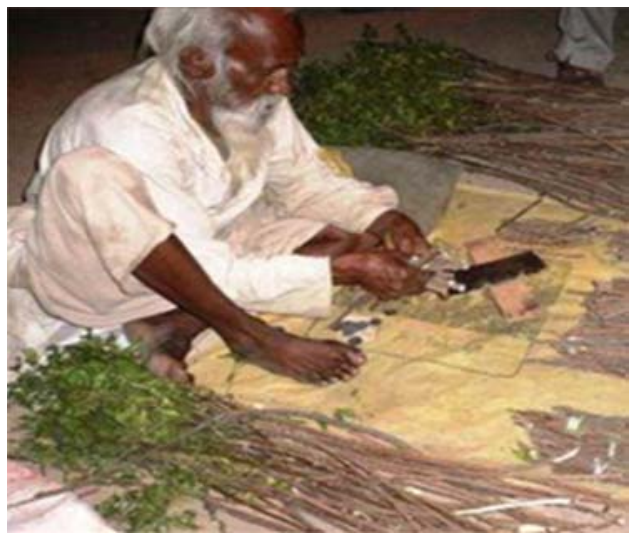

Fig. 65. Slender branches of neem are being cut into pencil length

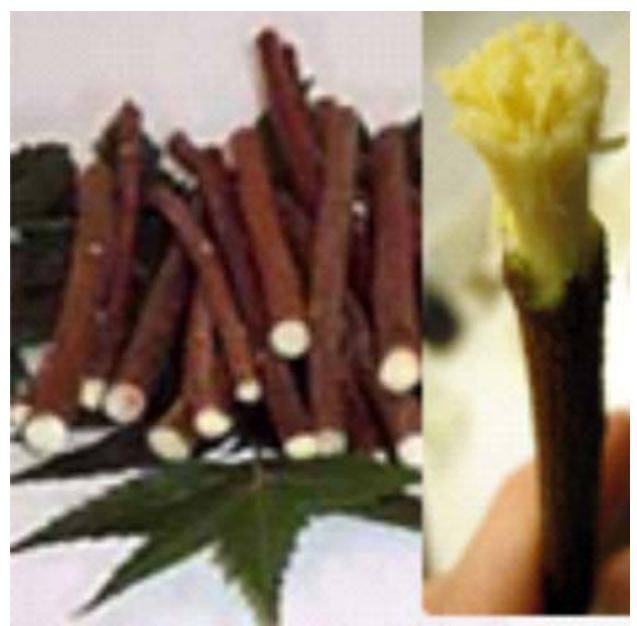

Fig. 66. Fresh twigs (left) and a partly chewed stick (right) as disposable chew sticks.

elaborate ritual involved in locating an appropriate tree and carving the idols, decorating them and taking them out in a procession in specially decorated chariots (Rathayātrā) with heavy wooden wheels. The English word 'juggernaut' is derived from this massive chariot and also means a huge and overwhelming force. Several lakhs of devotees attend this festival from India and abroad. A good deal of preparation is made by the Odisha State Government in maintaining law and order, crowd management, health issues, transport services, parking facilities and safety measurements. The most recent Nabakalebara festival was held on July 18, 2015. (www.rathayathra.net).

\section{JACKWOOD}

The Latin name of jackwood is Artocarpus heterophyllus Lam. (Family Moraceae). It is a large evergreen tree principally raised in the states of Kerala, Karnataka, Goa, Maharashtra and parts of Tamil Nadu. The tree is important more for the delicious, massive fruits measuring 30-60 cm long, weighing over 9-18 kg (the heaviest being $50 \mathrm{~kg}$ ) (Fig. 67) and containing a large number of seeds, each enclosed in a yellowish or cream-coloured, sweet, juicy and aromatic sheath which is the edible part. Unripe fruits are used as vegetable. Minced raw jackfruit is prepared like kīmā -a meat preparation with spices, or made into pickles.

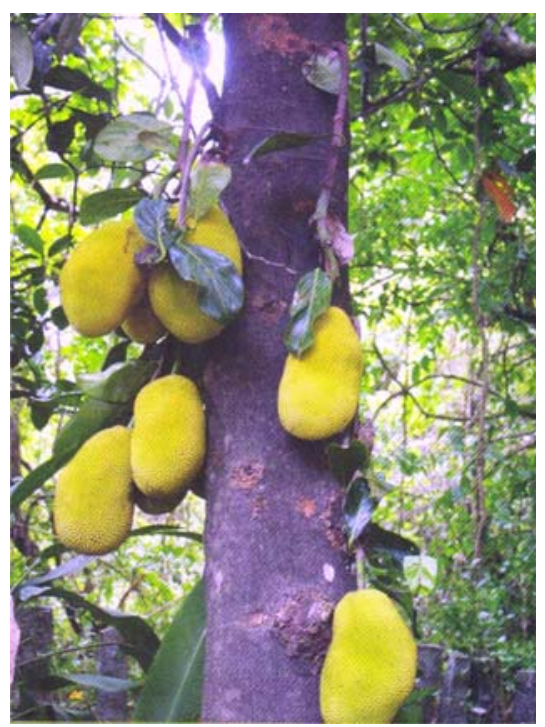

Fig. 67. Jackwood tree bearing massive fruits

The ripe sheaths are eaten fresh or preserved in syrup. Seeds are rich in starch. The evergreen, shiny leaves are stitched with split grass pins and made into platters on days of festivals or weddings. Wood is used for furniture, turnery and inlay work.

Importantly, the wood is in great demand as it is ideally suited for making of musical instruments used in Carnatic music i.e; vinnā or veena, tambura (tānpurā) and mrdarigam. Vīnā is a stringed instrument associated with Sarasvati, the goddess of learning; (she is also called Vīn $\bar{a}$ 
pustaka dhärini; bearer of vinna and books). Tambura or Tānpura $\bar{a}$ is a drone instrument generally used by vocalists. Mrdangam is a drum played horizontally, with the sides covered with goat or cow skin. With so many virtues, Jackwood is a truly iconic tree of India.

The wood when first cut is of a brilliant orange colour, which darkens to purplish black. It is compact and heavy. The grain is hard and close. Histologically, the diameter of the lumen of the wood vessels is smaller than those in other woods. The wood tissue is highly lignified and the walls are thick. The percentage of moisture in the wood is less than 10, which ensures high elasticity. The wood is easy to season and work with and gives a good smooth finish. The presence of interlocked grain, however, necessitates the use of shaping tools.

The special feature of Jackwood is that it gives a very sharp resonance and has a low acoustic loss factor. The trees growing in the red laterite arid soil of Pudukkottai (Tanjore district) yield wood that conforms to the above criteria and have been found to be best suited for the manufacture of mrdangams and other musical instruments.

\section{SHEESHAM}

Sheesham or Sissu (Dalbergia sissoo DC.) is a deciduous tree that bears indehiscent fruits (commonly called the Indian rosewood) native to India (Fig. 68). Sheesham is a premier timber species and is also used as fuel wood and for shade. It is planted as an avenue tree. The heartwood has a beautiful irregular grain structure, which is distinctive in appearance (Fig. 70) and can be polished to a fine finish. The heartwood is strong and durable, maintaining its shape during handling and construction.

It is an ideal material for decorative carvings (Fig. 71) and is easy to season. Saharanpur in Uttar Pradesh (U.P.) is famous for

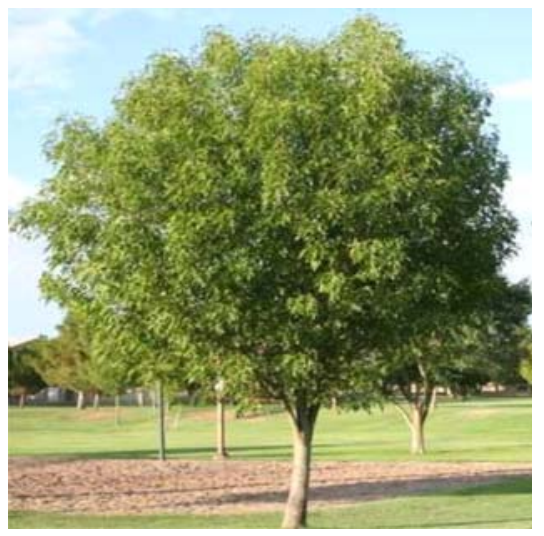

Fig. 68. Habit of Dalbergia sissoo

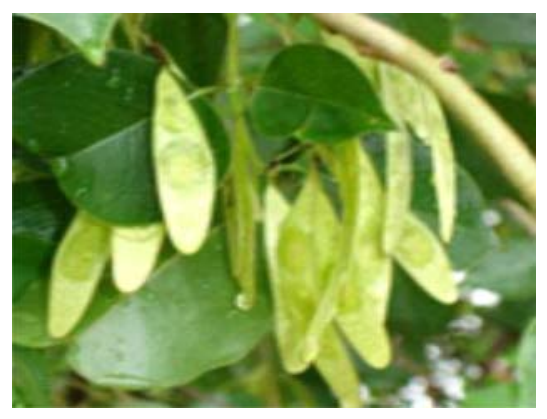

Fig. 69. A twig bearing tender fruits

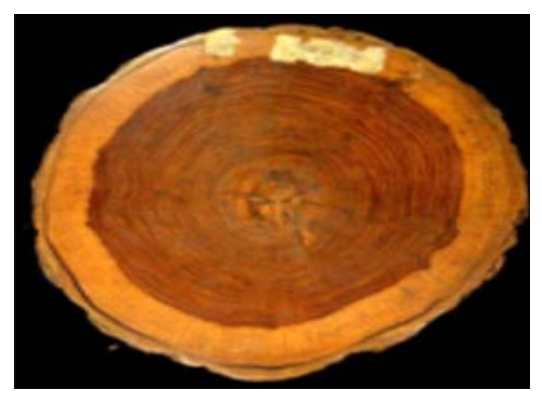

Fig. 70. A transverse section of the log showing prominent heartwood in the centre and sapwood in the periphery

woodcarving (Fig. 72, 74) and in-lay work using ivory (presently replaced by plastics). The most precious item of export from Saharanpur and nearby towns is the exquisitely carved, foldable wooden screens (Fig. 73). The wood is also used for preparing the bayān (bāya) of the tabla , the most important percussion instrument of Hindustani classical music. Dalbergia latifolia is the East Indian Rose wood or Bombay Blackwood that occurs in the Western Ghats, notably in Coorg 


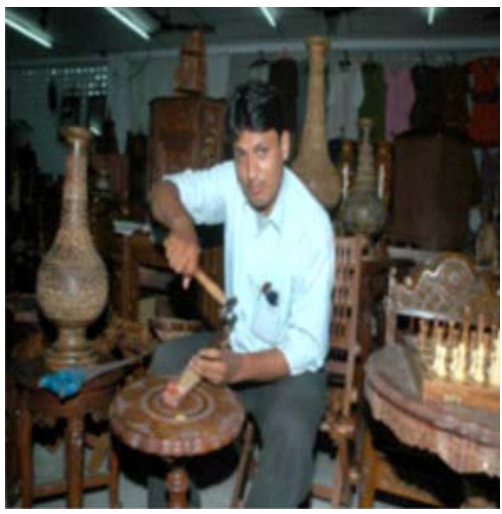

Fig. 71. A Sheesam wood workshop where several wood products have been made by hand

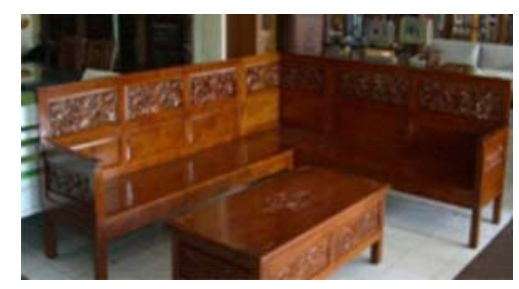

Fig. 72. An exquisite sofa set with a teapoy

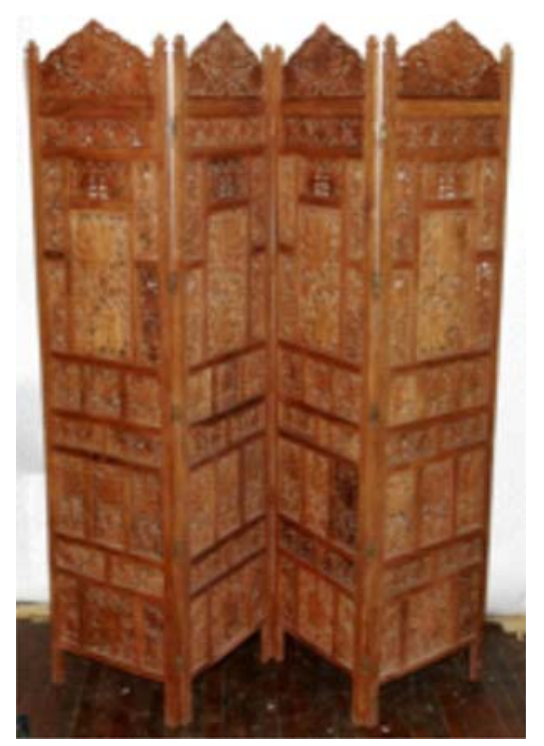

Fig. 73. Famous wooden screen of Saharanpur

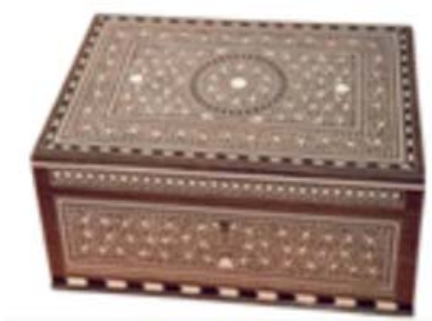

Fig. 74. A trinket box with inlay work made of the same wood and ranks among the finest woods for furniture paneling and carving. It is one of the most expensive woods.

\section{Palmyra Palm and Talipot Palm}

The Egyptians had used the first manmade paper like substance derived from a reed called the papyrus (Cyperus papyrus) growing on the banks of the river Nile in the delta of Egypt as early as 2500 BC. Around 105 AD the Chinese discovered that paper could be made from mulberry bark and old linen. Arabs improved this technique between 704 to $750 \mathrm{AD}$. It reached Europe, Iraq, Baghdad and Damascus by $1100 \mathrm{AD}$. The thin, papery birch bark (Betula bhojapatra) native to the Himalayan region of India growing at elevations up to $4500 \mathrm{~m}$ was available only in small strips. This material was flimsy and ephemeral. Fine brushes were necessary to paint the letters.

In the remote past leaves of two palms, Palmyra or Asian fan palm Borassus flabellifer L. (Fig. 75) and Talipot palm Corypha umbraculifera L. (Fig. 77) (also talipatra in Sanskrit) with very large fan shaped leaves (Fig. 76) were used as writing and painting materials in southern India and in parts of east and southeast Asian countries.

Large collections of palm leaf manuscripts are preserved in India, Myanmar and Sri Lanka in the custody of many of the old libraries, temples, monasteries, granthalayas, mutts and learned institutions and individuals. In written form, this vast corpus of literature is recorded history spread over different languages and scripts and depict ancient cultures. Therefore, the preservation of palm leaf manuscripts is an obligation and a responsible duty.

Palm leaf is three times stronger than handmade paper with high tensile strength. The palm leaves need to be processed in order to make the leaves suitable for writing, a process known as seasoning. The mode of preparation differs 


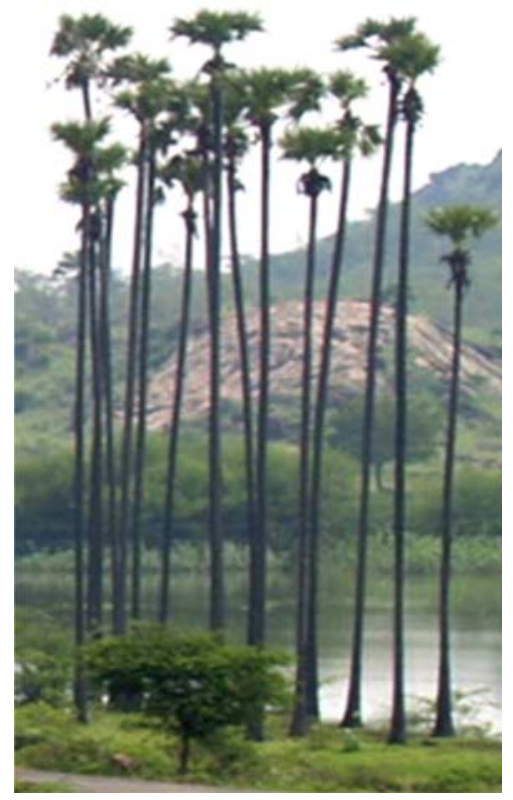

Fig. 75. Asian palmyra palm trees (Borassus flabellifer), on way to Mahabalipuram from Chennai

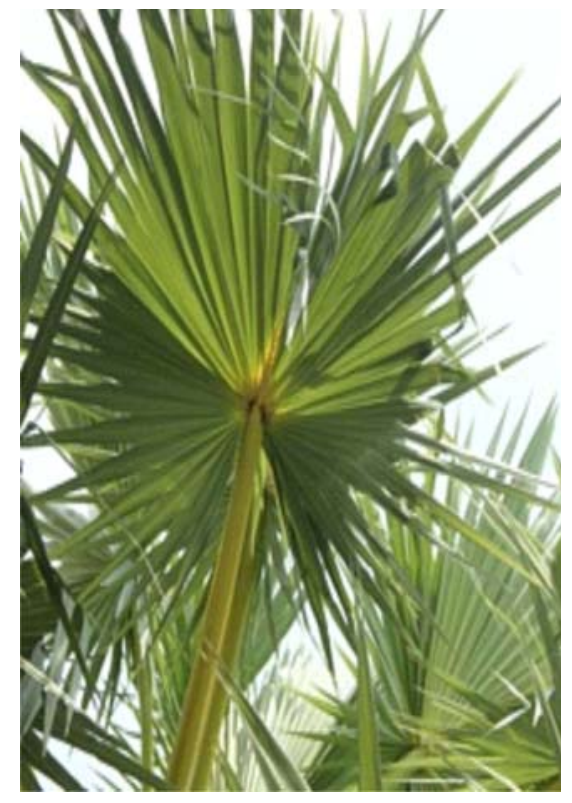

Fig. 76. A single leaf of palmyra palm showing typical palmate leaves, which is removed, dried and seasoned

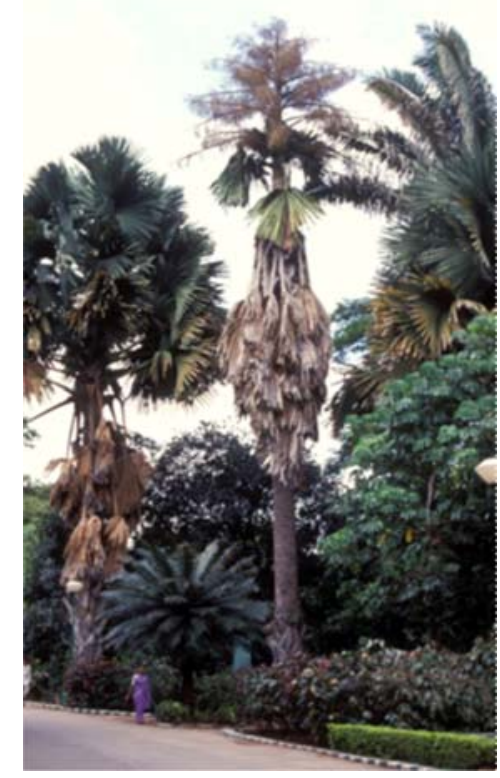

Fig. 77. Two talipot palm trees, one of which is showing profuse flowering at the apex according to the species from which the leaf is obtained. Writing materials prepared from the leaflets of Borassus flabellifer (Asian Palmyra palm) and Corypha umbraculifera (talipot palm) differ in a number of ways. Whereas the Asian Palmyra palm is found in India, Myanmar and Sri Lanka, the Talipot palm is distributed in Peninsular India and Sri Lanka. In Corypha, leaf veins are prominent in both transverse and vertical directions forming a network. A thick cuticle is present above the epidermis. In contrast, the leaflets of Borassus have a thin a cuticle and prominent parallel veins. Usually manuscripts prepared on Corypha are larger and superior in quality than those made from Borassus flabellifer. Writing material from C. umbraculifera will last longer than that from $B$. flabellifer. The process of preparing palm leaf manuscripts in southern India has been outlined by Kumar (2009). It is summarized below. There are several ways of processing palm leaves, depending on the region. The methods used in South India, in Orissa and other Southeast Asian countries are different. However the basic method of palm leaf preparation for writing is as follows (Patnaik 1989:16-17): Palm leaves are first cut from the trees before they could dry up and become brittle. In general, only a half opened palm leaves in young shoots have been found suitable. These are cut into required sizes, boiled in water to render them soft. After drying in shade the midrib (middle ridge) is removed, the desired portion is pressed, polished and trimmed (from $15 \mathrm{~cm}$ to $60 \mathrm{~cm}$ in length and from 3 to $12 \mathrm{~cm}$ in width). Then holes are made on either side of the leaves with a redhot wire. A string (usually of cotton) is passed through the holes to hold the leaves together. Two wooden planks of the required dimension are then placed above and below the manuscript as covers to protect the trimmed leaf strips, and are stored dry until they become flat and suitable for writing (Fig. 80). These wooden boards were sometimes painted or decorated artistically and the name of the contents was painted. Finally, the bundle of written manuscript was wrapped in cloth to keep it free from dust (Agrawal, 1984).

Most of the surviving ancient literature is written on the leaves of Corypha. A severe 
problem faced in deciphering the content of old manuscript is that the leaves almost appear blank. This is overcome by applying a mixture of citronella oil and lamp soot. The letters reappear (Fig. 79). The other notable aspect is that on an average the life span of a bound manuscript is roughly 200-300 years. An article that appeared in the New Indian Express (June 28, 2011), states that the average life of a palm leaf manuscript in the State Museum of Odisha is 500 years.

Writing on palm leaflets requires training and practice. The writer uses a stylus made of iron, silver and brass. It is about $25-30 \mathrm{~cm}$ in length, having a bulbous middle portion for resting against the hand with tapered pointed ends (Fig.78). In southern India, the common scripts used for the majority of palm leaf manuscripts are in Malayalam (Vattezhuthu or Kolezhuthu), Sanskrit, Tamil and Kannada.

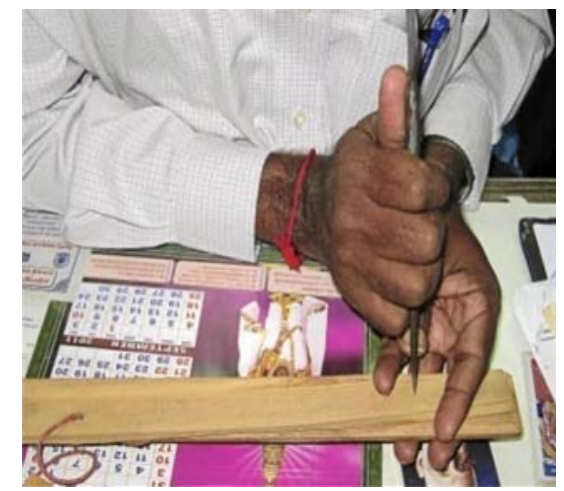

Fig. 78. Writing is done with the help of metal stylus and a suitable ink

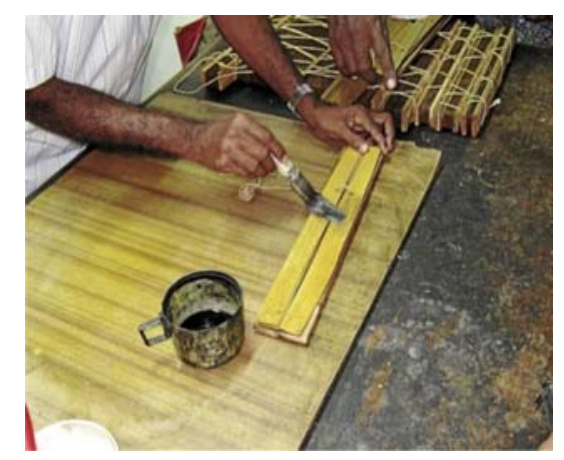

Fig. 79. A mixture of citronella oil and lamp soot is applied gently to make the original lettering on the palm leaf manuscript clearer

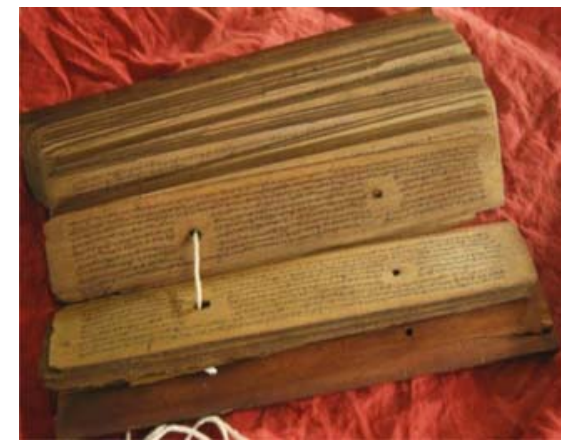

Fig. 80. An old manuscript with two holes to show that the old type palm leaf manuscript

The Government Oriental Library was set up in 1891 by the then Maharaja of Mysore, Chamarajendra Wodeyar (1863 -1894), in a magnificent heritage building (Fig. 81), blending several European architectural styles and housing nearly 60,000 palm-leaf manuscripts from antiquity. This is presently named The Oriental Research Institute (ORI).

In 1905, Dr. R. Shamashastry (Fig. 82), a refined scholar of Sanskrit, Prakrit, English, Kannada, German, French and other languages and who had also learnt various ancient scripts of India, was the Librarian and later Curator of the Library. He had deep interest, rigour and patience to examine a large number of palm leaf manuscripts stocked up. Fortuitously, he discovered the palm leaf manuscript of

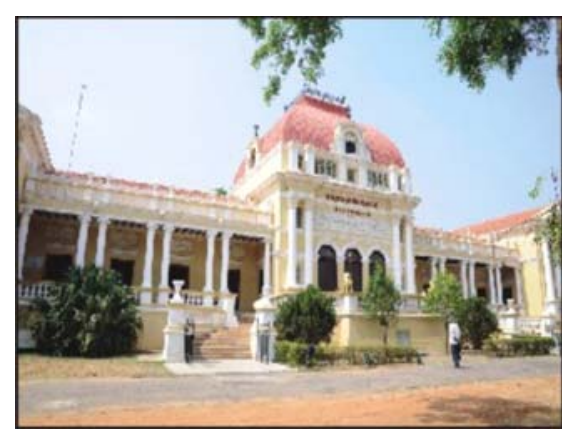

Fig. 81. Building of Oriental Research Institute, Mysore

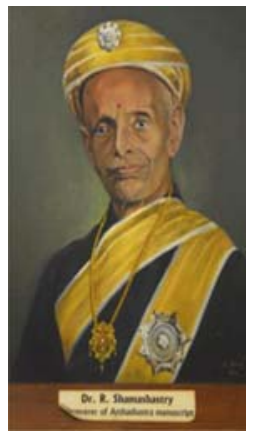

Fig. 82. Dr. S. Shamashastry discoverer of Arthaśāstra manuscript. 
'Arthaśāstra' written by Kautilya or Cānakya (350-272 B.C.). Cānakya was an Indian teacher at the ancient University of Takshashila, probably the oldest university in the world. He was a philosopher, economist, jurist and adviser to Chandragupta Maurya and later, his son Bindusara. He was the author of the ancient text of Arthaśāstra (economics and political science). Although the existence of this work was known, there was no recorded proof for it. It is a remarkable manuscript of the treatise on politics, military science, business management, administration, civil law, governance and taxation policy, gemmology and metallurgy. The training of horses and elephants is also included in it. Shamashatry brought out an English translation of this manuscript in the form of a book with the title: 'Kautilya’s Arthaśāstra' in 1909. This work was hailed as an outstanding addition to our knowledge by historians, scholars and academicians throughout the world, acknowledging that India did have an enviable textual history of administration. Even the British who lorded over India were surprised by this discovery.

Not all the fame of the work and its discovery, however, seem to have inspired enough enthusiasm for the careful preservation of this manuscript. Instead of a safe or a weatherproof glass case, the manuscript is preserved in an unlocked steel cupboard in the Director's office of the Oriental Research Institute in Mysore. A wrapping of red cloth, and a spray of preservative citronella oil (or lemongrass oil from Cymbopogon citratus), is all the protection the manuscript gets. Professsor Jagannath, an expert in manuscriptology at the ORI, puts it all in perspective. "Don't expect an autograph of Cānakya on these palm leaves,” he says. "This is perhaps only a recopy of a recopy made some 500600 years ago. It was with a pandit in Tanjore, who handed it over to the Institute not knowing what was written on it. Other such recopies were found elsewhere in India, but that was later, after our discovery.” He explains that the manuscript is in Sanskrit, but written out in the Grantha script and not Devanagari, since the Tamil script could not accommodate certain sounds from Sanskrit. Grantha was created to allow for the representation of those sounds in a script accessible to those who know Tamil.

The Indira Gandhi National Centre for the Arts (IGNCA) in New Delhi has an entire section devoted to the collection, storage, preservation, research and decoding palm leaf manuscripts. It has set up a National Mission for manuscripts to designate 15 Manuscript Conservation Centers all over India. IGNCA is one of them, which holds awareness campaigns, workshops regarding conservation of manuscripts and conducts preventive treatment courses on manuscripts and their storage to scholars for various institutions.

\section{HARSingar}

Also named Pārijāta, Śiuli, Śefālikā or Night blooming Sad Tree (Nyctanthes arbor-tristis L.), the plant occurs all over India, Pakistan, China, Nepal and Thailand. It is a large shrub up to $10 \mathrm{~m}$ tall with opposite-decussate leaves that are rough and hairy on the ventral side (used as sand paper during World War II). Flowers occur terminally or in the axils of leaves. Petals are white and united with 5-8 lobes with a deep orange coloured tube (Fig. 83). The dye extracted in water from the tubes finds use in colouring clothes and Buddhist robes in Sri Lanka. The leaves have antibacterial, antioxidant and anthelmintic properties. Shiuli is an ancient medicinal plant commonly planted in home gardens. The plants bloom in the evening, emitting a pleasant aroma. The corollas are shed at night forming a beautiful dew mixed carpet on the ground below (Fig. 84). The plants start flowering in late August-September. People who wish to use the flowers for worship usually spread a clean cloth beneath the tree late in the evening to gather them the next morning. 


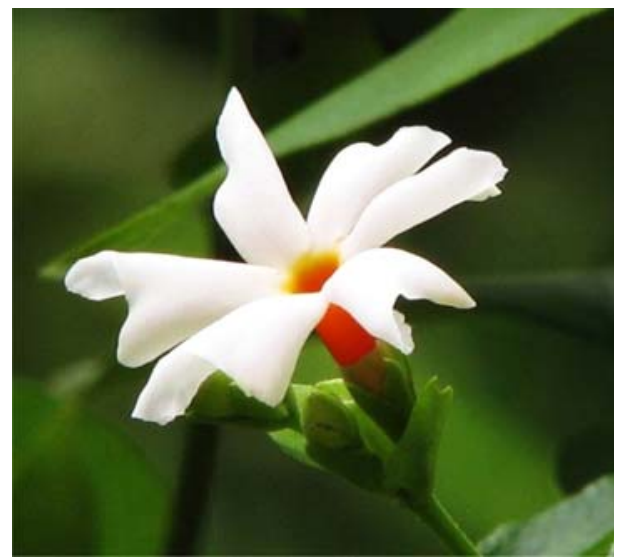

Fig. 83. A portion of the Harsingar (Nyctanthes arbor-tristis) plant showing a fully open flower with an orange coloured centre

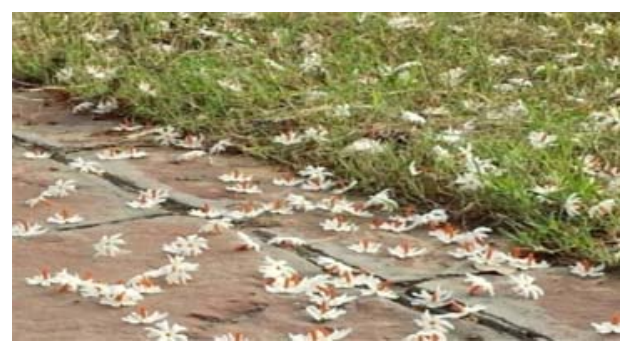

Fig. 84. The fallen flowers in the morning on the floor

Siuli is the official flower of the State of West Bengal and of the Kanchanaburi province in Thailand.

\section{6. СНАMРАК}

Also known as Campaka, Magnolia champaca (L.) Baill. Ex. Pierre (formerly Michelia champaca) of the family Magnoliaceae, is an Asian tree that generally reaches a height of $30 \mathrm{~m}$ (Fig. 85). It is native to India, where it occurs in humid tropical evergreen forests from 250-1500 $\mathrm{m}$ in elevation and is sacred to Hindus and Buddhists. It is found throughout Indo-China, Malaysia, Sumatra, Java, southwestern China and Taiwan. Its native range is difficult to determine, as it has been dispersed extensively by humans throughout Southeast Asia and Indonesia. The genus Magnolia contains about 40 species. An unusually large and old campaka tree occurs in the Biligiri Rangana Hills (B.R. Hills) forest in the Mysore district of Karnataka.

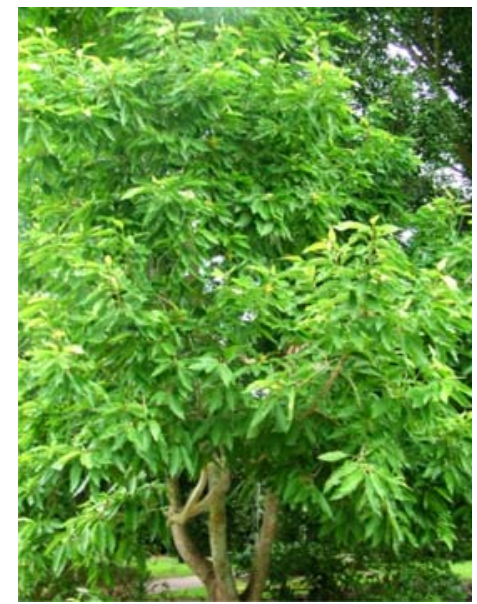

Fig. 85. A young flowering tree of Magnolia campaka, that generally bears light yellow flowers

This individual is a living monument named 'Dodda Sampige' in Kannada ('Large Champak tree') (Fig. 88), believed to be more than 2000 years old. The tree is approximately $20 \mathrm{~m}$ broad. It is located $4 \mathrm{~km}$ away from B.R. Hills. Dodda sampige is the largest champak tree recorded from India with many lingams placed close to it. The site is considered holy; the soliga tribals mainly worship this tree.

Campaka is a timber tree with a finegrained wood employed in the construction of buildings, furniture, toys, and carvings. The other uses are in preparing packing cases, crates, tea chests and plywood. The wood is strong and moderately durable. The essential oils extracted from the fragrant flowers are a common ingredient of perfumes. It is yellow or orange with a heady aroma. Women often wear the flowers as an adornment in leis or on hair. The bark is aromatic and commonly sold as an adulterant of cinnamon. The flowers are used in worshiping and decorating deities. The fruits are follicles, which dehisce to expose bright red seeds (Fig. 87).

It is common to see Champak trees in temples and home gardens. The wood is an ideal material to prepare bead chains. Champak is common in sacred groves in Tamil Nadu state. 


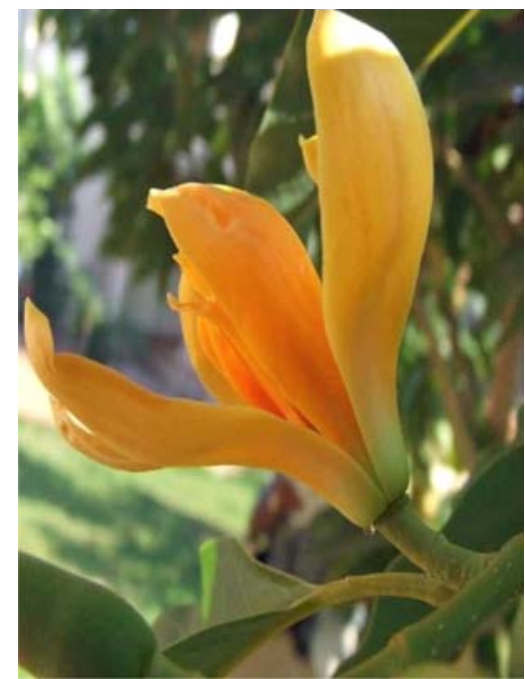

Fig. 86. A flower of the orange variety

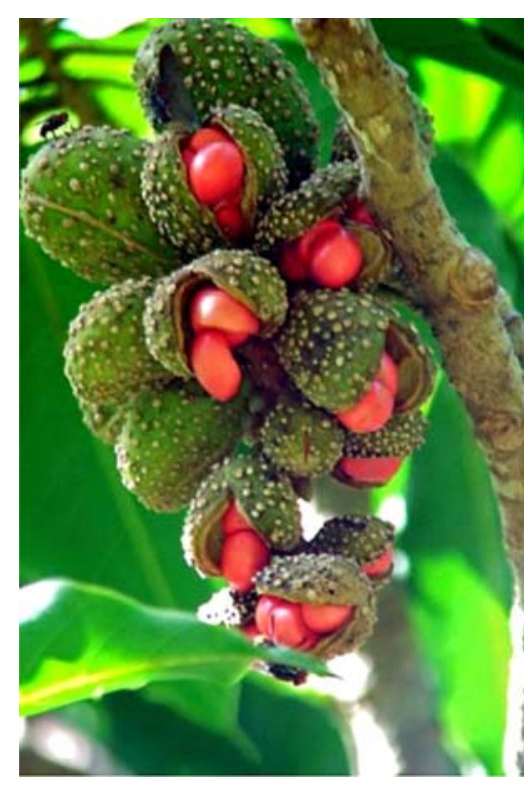

Fig. 87. Open fruits with red seeds

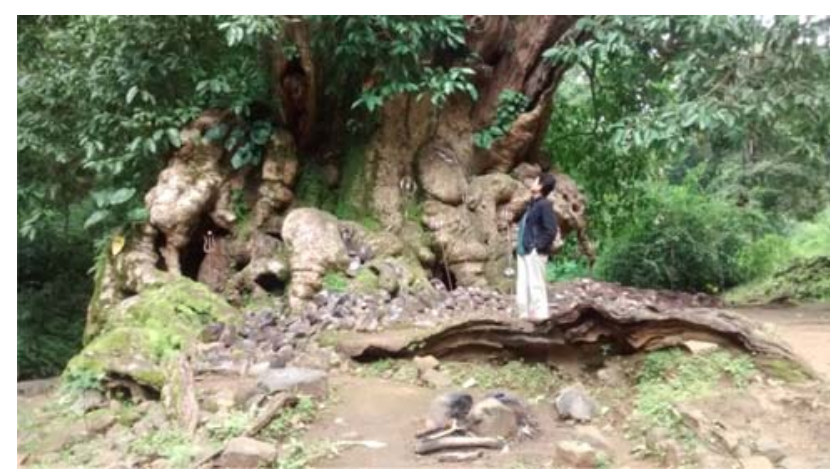

Fig. 88. The 'Dodda Sampige' (The Great Champak Tree) near B.R. Hills (see details in the text)

\section{ACKNOWLEDGeMENTS}

The author thanks Professor P. Majumder for inviting him to participate in the seminar. In preparing the paper, I extend my appreciation to Ms. Deepti Uthaman for the enormous amount of diligence in collecting and collating the text and the illustrations. I am indebted to Drs. M. Sanjappa and Paramjit Singh, former and present Directors of Botanical Survey of India, respectively for their valuable comments. Dr. Anuradha Agrawal, Principal Scientist, NBPGR, New Delhi and Dr. Arun Kumar, Institute of Wood Science and Technology, Bengaluru generously provided valuable inputs and illustrations. The Current Science Association has given permission to reproduce figures $1 \mathrm{a}, \mathrm{c}, \mathrm{d}, \mathrm{e}, \mathrm{f} \& \mathrm{~g}$ that had appeared in 2012, Vol. 103 pp 1408-1416. Fig. 61 has been reproduced from the publication 'Living Landmarks of Chennai' by Nizhal, and Fig. 67 has been taken from 'A Bibliography of Sanskrit Works in Life Sciences’ by Dr. S. Sundara Rajan with his permission. Out of 88 illustrations, 28 are from my personal collection and the rest are from different websites.

\section{BibLIOGRAPHY}

Agrawal A. and Tyagi, R.K. In vitro conservation and cryopreservation of genetic resources of Musa spp. A review of the recent developments with special reference to India. International Journal of Innovative Horticulture 3(2014):115-133.

Agrawal, Om Prakash. Conservation of Manuscripts and Paintings of South-east Asia, Butterworths \& Co Ltd., London 1984.

Ambasta S.P.; Kamla, Ramachandran; Kashyapa K. and Chand, Ramesh. The useful Plants of India. National Institute of Science Communication and Information Resources. Council of Scientific \& Industrial Research. 2006.

Chadha, K.L. Handbook of Horticulture. Directorate of Knowledge Mangement in Agriculture. Indian Council of Agricultural Research. Krishi Anusandhan Bhavan, Pusa, New Delhi-10012. 2011.

Denham T.; de Langhe, E. and Vrydaghs, L. Special issue: history of banana domestication. Ethnobotany 
Research and Applications 7:163-164. Leiden. 1995. Asia and the Pre - modern World Economy, International Institute for Asian Studies. 2009.

Kumar, D.U.; Sreekumar, G.V. and Athvankar, U.A. Traditional writing system in Southern India -Palm leaf manuscripts. Design Thoughts. 2009. (www.idc.iitb.ac.in/resources/dt-july-2009/Palm.pdf).

Mabberley, D.J.. Mabberley’s Plant Book: A portable dictionary of Plants, their classification and uses. $3^{\text {rd }}$ Ed. Cambridge University Press. 2008.

MacClure, F.A. The Bamboo- A Fresh Perspective, Harvard University Press, Cambridge, 1966.

Pande, Suruchi \& Pande, Satish. Flora, Fauna and Nature in Buddhist Thought. Conservation Ethics in Indian Culture: No.1. Ela Foundation \& Directorate of Social Forestry, Forest Department, Maharashtra. 2015.

Quattrocchi, U. CRC World Dictionary of Plant Names: common names, scientific names, eponymns, synonyms and etymology. Vols. 1 to 4 CRC Press, Boca Raton, USA. . 2001.

Renuka C. and Sreekumar V.B. A field Guide to the Palms of India. Kerala Forest Research Institute. Peechi680653. 2012.

Singh, L. J. Musa indandamanensis L. J. Singh: A new species (Musaceae) from the Bay Islands, India. Taiwania 59: 26-36. 2014.

Swangpol S. C.; Traiperm, J; P. Somana; Sukkaewmanee, N.; Srisanga, P. and Suksathan, P. Musa nanensis, a new banana (Musaceae) species from Northern Thailand. Systematic Botany 40(2015):426-432. 2015.

Uma S.; Saraswathi, M.S.; Backiyarani S.; Durai, P. and Mustaffa, M.M.. Less exploited landraces of banana in India. Protection of Plant Varieties and Farmers' Right Authority, New Delhi and National Research Centre for Banana (ICAR), Tiruchirapally, Technical Bulletin no. 21, p. 522014.

http://bharatkalyan97.blogspot.in/2012/11/a-tribute-toshamashastry-discovery-of.html

https://www.library.cornell.edu/preservation/ librarypreservation/mee/preservation/palmleaf.html

h t t p : / / w w w . l i ve m in t . c o m / L e is u r e / 5zOpdwBBKuxFKKpusmQ930/Core-ingredientBlack-pepper-the-spice-that-rewrote-histor.html

(ICAR-Indian Institute of Spice Research, Black pepper Extension pamphlet November 2015) http://www.thehindu.com/todays-paper/tp-features/tpmetroplus/a-canopy-of-life/article6996789.ece

\section{Pictures References}

1. Dr. Paramjit Singh. BSI.

2a. http://colorlibrary.blogspot.in/2012/09/worlds-biggesttree-timmamma-marrimanu.html

2b. ht t p : / / indianrecords.blogs pot.in / 2013_05_01_archive.html

3. http://www.vallamai.com/

4. http://www.thehindu.com/todays-paper/tp-features/tppropertyplus/bend-it-like-banyan/article5668810.ece

5. www.baijujoseph.com.

6 http://www.lonelyplanet.com/news/2015/02/20/ obamas-tree-not-dead-just-resting-say-indian-officials/ peepal-tree-sharada-prasad-cs/

7. https://en.wikipedia.org/wiki/Ficus_religiosa

8. https://en.wikipedia.org/wiki/Bodh_Gaya

9. http://industrialtour.com/bodhgaya-industrial-tour/

10. Pande \& Pande, 2015. @ Ela Foundation and as credited.

11. http://www.willgoto.com/1/146008/liens.aspx

12a -16 Arun Kumar AN, Joshi Geeta, Mohan Ram HY. Sandalwood: history, uses, present status and the future. Current Science. 103: 1408-1416. 2012

17. H.Y Mohan Ram

18. Kumari Pushpa \& Singh Paramjit. Bamboos of Meghalaya. Botanical Survey of India, CGO Complex, Salt Lake City, Kolkata-700 064. 2014.

19. H.Y Mohan Ram

20. https://www.youtube.com/watch?v=79tOKckjx9o

21- 25. H.Y. Mohan Ram

26. http://www.minimalisti.com/architecture/06/bamboohouse-design-ideas.html

27. https://en.wikipedia.org/wiki/Durga_Puja

28. www. Punamflutes.com

29. Dr. Anuradha Agrawal

30. H.Y. Mohan Ram

31-32. Dr. Anuradha Agrawal

33-35. H.Y. Mohan Ram 
36. http://www.dailymail.co.uk/

37. https://transferwise.com/blog/2014-05/why-coconutwater-is-now-a-1-billion-industry/

38. http://www.travankore.com/Coir-Art-TRITMP019Hand\%20crafted-Online

39. http://dir.indiamart.com/coimbatore/coir-rope.html

40. https://whereverilaymytrilby.wordpress.com

41. http://www.travelingbeats.com/blog/kozhikode-calicutdistrict-travel-info-kerela

42- 43. http://thebigjackfruittree.com/sunset-at-kappadbeach/

44. http://www.growthis.com/how-to-grow-black-pepper/

45. http://www.premiumgroup.co.in/

46. www.stockfood.com

47. http://healthyliving.natureloc.com/cardamom-queenof-spices/

48-49. H.Y. Mohan Ram.

50. http://turmericworld.com/medicinal-uses.php

51- 54. H.Y Mohan Ram.

55. http://www.fluorideprotection.org/tamarind.html

56. https://en.wikipedia.org/wiki/Tamarind

57. http://www.keralaayurveda.biz/content/awesometamarind-and-its-ayurvedic-benefits

58 http://tarafate.com/tamarind.html

58. https://oasisbakery.com.au/products/tamicon-tamarindconcentrate-227g.

59-60. H.Y. Mohan Ram
61. Nizhal. Chennai

62. H.Y. Mohan Ram

63. http://www.sundarodisha.wapka.mobi/site_17.wml

64-66. H.Y. Mohan Ram.

67. Dr. S. Sundara Rajan

68. http://deserthorizonnursery.com/plants/evergreen-trees/

69. http://www.prota 4 u. org/protav8.asp? p= Dalbergia + sissoo

70. Picture from Department of Botany, University of Delhi

71. H.Y. Mohan Ram

72. http://www.natashascafe.com/

73-75. H.Y. Mohan Ram

76. http://uforest.org/Species/B/Borassus_flabellifer.html

77. http://www.thestar.com.my/travel/asia/2013/11/16/ treasure-trove-of-ancient-manuscripts-in-thanjavurindia/

\section{8-80. H.Y. Mohan Ram}

81. https://tamilbrahmins.wordpress.com

82. https://www.flickr.com/photos/hgmphotos/6276340932

83. https://www.goodreads.com/author_blog_posts/ 4742109-a-nostalgic-sniff-later

84. http://www.oramsnurseries.com.au/product/micheliachampaca-himalayan-magnolia/

85. https://australianseed.com/shop/item/micheliachampaca-

86. https://www.flickr.com/photos/kanakoa/507963615

87-88. Courtesy: Dr. Amita Baviskar 